\title{
Synthesis of spirocyclic scaffolds using hypervalent iodine reagents
}

\author{
Fateh V. Singh*, Priyanka B. Kole, Saeesh R. Mangaonkar and Samata E. Shetgaonkar
}

\section{Review}

\section{Address:}

Chemistry Division, School of Advanced Sciences (SAS), VIT

University, Chennai Campus, Chennai-600 127, Tamil Nadu, India

Email:

Fateh V. Singh ${ }^{*}$ - fatehveer.singh@vit.ac.in

* Corresponding author

Keywords:

hypervalent iodine reagents; iodoarenes; natural products; oxidative cyclization; spirocyclic compounds

\section{Open Access}

Beilstein J. Org. Chem. 2018, 14, 1778-1805.

doi:10.3762/bjoc. 14.152

Received: 23 March 2018

Accepted: 18 June 2018

Published: 17 July 2018

This article is part of the Thematic Series "Hypervalent iodine chemistry in organic synthesis".

Guest Editor: T. Wirth

(C) 2018 Singh et al.; licensee Beilstein-Institut.

License and terms: see end of document.

\begin{abstract}
Hypervalent iodine reagents have been developed as highly valuable reagents in synthetic organic chemistry during the past few decades. These reagents have been identified as key replacements of various toxic heavy metals in organic synthesis. Various synthetically and biologically important scaffolds have been developed using hypervalent iodine reagents either in stoichiometric or catalytic amounts. In addition, hypervalent iodine reagents have been employed for the synthesis of spirocyclic scaffolds via dearomatization processes. In this review, various approaches for the synthesis of spirocyclic scaffolds using hypervalent iodine reagents are covered including their stereoselective synthesis. Additionally, the applications of these reagents in natural product synthesis are also covered.
\end{abstract}

\section{Review}

\section{Introduction}

The chemistry of spirocyclic compounds is a well established research area of organic and medicinal chemistry [1-5]. These scaffolds are common structural motifs found in various classes of naturally occurring systems [6-8]. More importantly, various natural and synthetic products containing a spirocyclic ring are currently used as commercial drugs for the treatment of several health problems $[9,10]$. Annosqualine (1) is an isoquinolinecored alkaloid and it was isolated in 2004 from the stem of Annona squamosa [11] (Figure 1).

Griseofulvin (2) is a spirobenzofuranone-based naturally occurring compound which was isolated from Penicillium griseofulvum in 1939 [12]. In 1959, it was launched in the market as antifungal agent for the treatment of ringworm in human beings and animals $[4,13]$. Stepharine $(3)$ is a member of the proaporphine alkaloid family and isolated from an angiosperm Stephania glabra [14]. Tofogliflozin (4) is a synthetic spirocyclic glycoside that was launched as antidiabetic agent in 2012 in Japan [15]. Rolapitant (5) is a marketed drug that was ap- 
<smiles>COc1c(O)cc2c(c1OC)CCN1C(=O)C3(C=CC(=O)C=C3)C[C@H]21</smiles>

annosqualine (1)

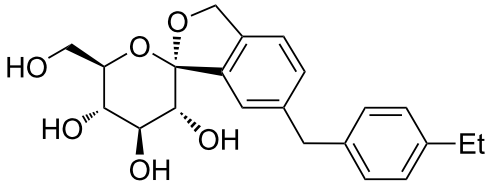

tofogliflozin $(4)$<smiles>COC1=CC(=O)C[C@H](C)[C@]12Oc1c(Cl)c(OC)cc(OC)c1C2=O</smiles>

griseofulvin (2)

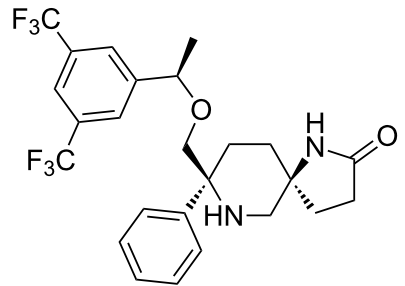

rolapitant (5)<smiles>COc1cc2c3c(c1OC)C1(C=CC(=O)C=C1)CC3NCC2</smiles>

stepharine (3)

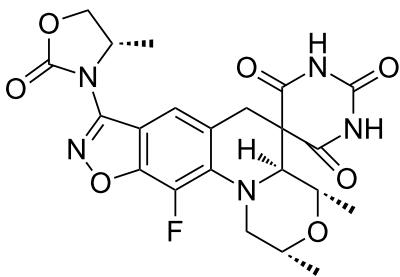

ETX0914 (6)

Figure 1: The structures of biologically active natural and synthetic products having spirocyclic moiety.

proved in 2015 for the treatment of nausea and vomiting [16]. Compound $\mathbf{6}$ is a spiropyrimidinetrione analogue which is currently in clinical trials for the treatment of gonorrhea [17] There are several ways available in literature for the synthesis of spirocyclic compounds but most of them are associated either with transition metals or hypervalent iodine reagents [1-3].

Hypervalent iodine reagents provide various functional group transformation opportunities in organic chemistry. Their environment-friendly nature and mild reaction conditions makes them more attractive candidates for the replacements of various toxic metals in organic synthesis [18-31]. These reagents are more popular for their oxidizing properties [32-38] and electrophilic nature of different iodine(III) reagents has been explored to developed various synthetic transformation including rearrangements [39-62]. Hypervalent iodine chemistry has now become a well-established research area and various book chapters $[19,20,27]$ and review articles [21-24,31-35,60,63,64] appeared to explain the chemistry of these reagents. In the past two decades, a number of organic chemists used these reagents for the construction of a variety of spirocyclic scaffolds. In 2008, Quideau and co-workers published a nice review article where they have described various spirocyclization reactions using hypervalent iodine reagents via dearomatizations of aromatic phenolic species [32]. This review article is quite useful for readers who want to know the chemistry involved during the dearomatization of phenols and to find the relevant literature available until 2008. In this review article, various approaches for the synthesis of spirocyclic scaffolds using hypervalent iodine reagents are covered including stereoselective reactions.
Hypervalent iodine reagents are mainly popular for their oxidative properties but various iodine(III) reagents have been used as electrophiles. Numerous iodine(III) reagents have been successfully used to achieve diverse spirocyclic scaffolds. Phenols 7 or 11 having an internal nucleophile at ortho- or para-position can be used as starting material for the synthesis of orthoand para-spirocyclic compounds in the presence of iodine(III)based electrophiles (Scheme 1). Phenolic oxygen of compound $\mathbf{7}$ attacks to the iodine of $\mathbf{8}$ to form intermediate $\mathbf{9}$. Furthermore, on nucleophilic attack of the internal nucleophile to the orthoposition intermediate 9 converts to ortho-spirocyclic compound 10 with the elimination of the hypervalent iodine moiety. Similarly, para-spirocyclic compounds $\mathbf{1 3}$ can be achieved starting from compounds 11 and iodine(III) reagent 8 (Scheme 1). The synthesis of spirocyclic compounds can be achieved using stoichiometric or catalytic amounts of iodine(III) reagents. According to literature reports, both heterocyclic and carbocyclic spirocyclic compounds can be achieved using these reagents [27,32].

\section{Synthesis of spirolactones}

\subsection{Using stoichiometric amounts of iodine(III) reagents}

The history of the utility of hypervalent iodine reagents in the synthesis of spirocyclic compounds is going to become quite old now. Initially, iodine(III) reagents were applied for synthesis of spirocyclic in 1990s [65,66]. In 1991, Kita and co-workers [67] established the synthesis of spirohexadiones from $N$-acyltyramines using iodine(III) reagent. After these reports, numerous hypervalent iodine-mediated spirocyclizations were investigated and phenolic oxidations of substrates 


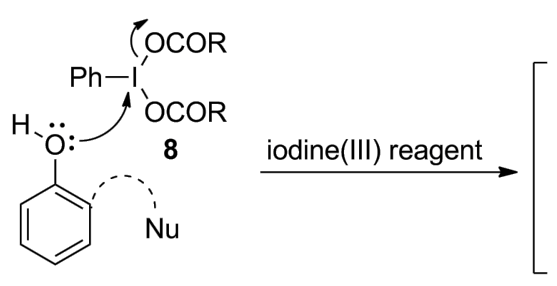

7

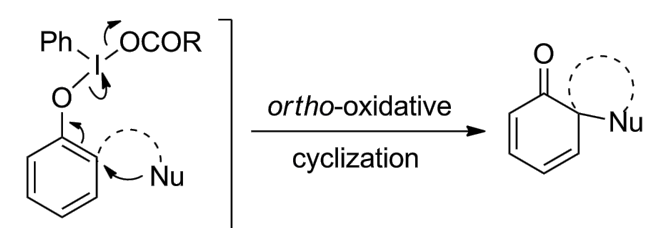

9
10

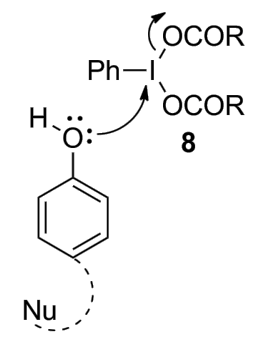

11

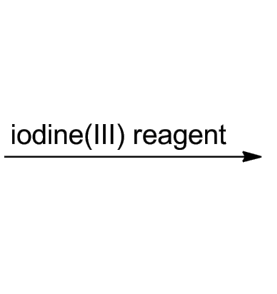

(1)

12

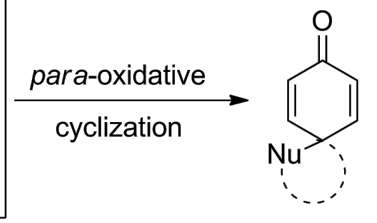

13

Scheme 1: lodine(III)-mediated spirocyclization of substituted phenols 7 and 11 to 10 and 13, respectively.

have been explored for the construction of spirodienone motifs $[21,64]$.

In 1993, Wipf and Kim [68] employed PIDA (15) for spirocyclization of N-protected tyrosine $\mathbf{1 4}$ to spirolactone $\mathbf{1 6}$. The spirocyclization reaction was carried out in methanol using stoichiometric amounts of PIDA (15) and spirolactone 16 was isolated in $35 \%$ yield (Scheme 2). Probably, the cyclization reaction proceeded via dearomatizaion of phenolic substrate $\mathbf{1 4}$ followed by nucleophilic attack of the carbonyl moiety of carboxylic group.<smiles>CC(=O)NC(Cc1ccc(O)cc1)C(=O)O</smiles>

14

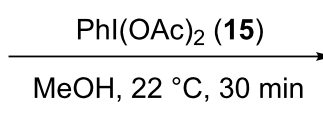

16: $35 \%$
Scheme 2: PIDA-mediated spirolactonization of $\mathrm{N}$-protected tyrosine 14 to spirolactone 16.

Furthermore, Giannis and co-workers [69] reported the synthesis of novel aminomethylpolystyrene-supported (diacetoxyiodo)benzene (PSDIB) reagents $\mathbf{1 7 a}$ and $\mathbf{1 7 b}$ starting from aminomethylated polystyrene with 4-iodobenzoic acid and 4-iodophenylacetic acid in two steps (Figure 2).

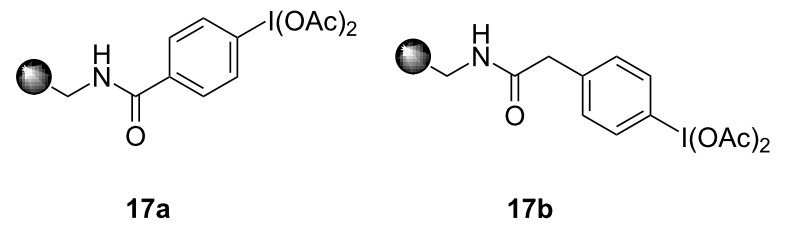

Figure 2: The structures of polymer-supported iodine(III) reagents 17 a and $17 \mathrm{~b}$.

Both polymer-supported reagents $17 \mathbf{a}$ and $\mathbf{1 7} \mathbf{b}$ were used in similar spirocyclizations of tyrosine 14 . Both tyrosine 14a and $\mathrm{N}$-protected tyrosine derivatives $\mathbf{1 4 b}, \mathbf{c}$ were used as starting material and results of their spirolactonization are summarized in Table 1 (Scheme 3).

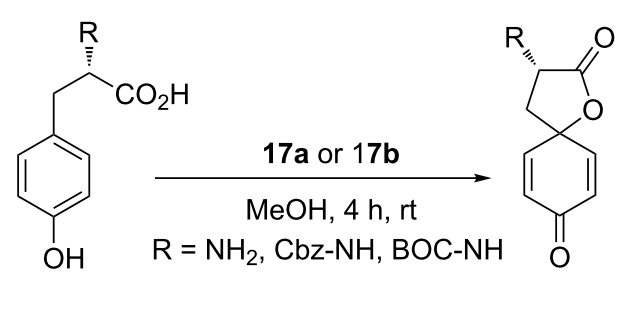

14

16

Scheme 3: Spirolactonization of substrates 14 to spirolactones 16 using polymer-supported reagents $17 \mathrm{a}$ and $17 \mathrm{~b}$.

The spirolactonization products $\mathbf{1 6}$ were isolated in excellent yields when reactions were performed with substrates $\mathbf{1 4}$ 
Table 1: Spirolactonization of substrates 14 to spirolactones 16 using polymer-supported reagents $17 \mathrm{a}$ and $17 \mathrm{~b}$.

\begin{tabular}{|c|c|c|c|}
\hline entry & substrate 14 & PS-iodine(III) reagent & 16 yields $(\%)$ \\
\hline 1 & 14a: $\mathrm{R}=\mathrm{NH}_{2}$ & $17 a$ & 82 \\
\hline 2 & 14a: $\mathrm{R}=\mathrm{NH}_{2}$ & $17 b$ & 80 \\
\hline 3 & 14b: $\mathrm{R}=\mathrm{Cbz}-\mathrm{NH}$ & $17 a$ & 25 \\
\hline 4 & 14b: R = Cbz-NH & $17 b$ & 26 \\
\hline 5 & 14c: $\mathrm{R}=$ Boc-NH & $17 a$ & 24 \\
\hline 6 & 14c: $\mathrm{R}=\mathrm{Boc}-\mathrm{NH}$ & $17 b$ & 25 \\
\hline
\end{tabular}

$\left(\mathrm{R}=\mathrm{NH}_{2}\right.$ ) having free amino group (Table 1, entries 1 and 2$)$. Notably, the poor yields were observed during the spirolactonization of N-protected tyrosine derivatives $\mathbf{1 4 b}$ and $\mathbf{1 4 c}$ (Table 1, entries 3-6). The advantage of this reaction is that the polymer-supported reagent can be regenerated and reused without loss of any significant activity [69].

In 2010, Kita and co-workers [70] developed another approach for PIDA-mediated spirolactonization of 1-( $p$-hydroxyaryl)cyclobutanols $\mathbf{1 8}$ to spirolactones $\mathbf{1 9}$ in good yields (Scheme 4). The reaction was initiated with formation of an intermediate $\mathbf{2 0}$ by the oxidation of the phenolic hydroxy group of $\mathbf{1 8}$, which rearranged to compound 21. Furthermore, water attacks the ketone moiety of $\mathbf{2 1}$ to form para-substituted phenol 22. The phenolic intermediate $\mathbf{2 2}$ is further oxidized with another molecule of PIDA (15) to form intermediate 23, which yielded the final product 19 on intramolecular cyclization [70].

Furthermore, Kita and his research group [71] reported an iodine(III)-mediated cyclization of arylalkynes $\mathbf{2 4}$ to spiro- cyclic products $\mathbf{2 6}$ by in situ-generated active hypervalent iodine species. In this report, para-substituted esters $\mathbf{2 4}$ were cyclized to corresponding spirolactones 26 using stoichiometric amount of bis(iodoarene) 25 with terminal oxidant $m$ CPBA in the presence of $\mathrm{TsOH} \cdot \mathrm{H}_{2} \mathrm{O}$ in TFE (Scheme 5). In this reaction, active hypervalent iodine species was generated in situ by the oxidation of bis(iodoarene) 25 using $m \mathrm{CPBA}$ as terminal oxidant.

In 2011, Kita and co-workers [72] investigated a more reactive $\mu$-oxo bridged hypervalent iodine(III) reagent used in the spirocyclization of phenolic substrates 27 to spirolactones 29. The reaction products were obtained in excellent yields using 0.55 equivalents of bridged iodine(III) reagent 28 in acetonitrile at room temperature (Scheme 6). Furthermore, a comparative study was done between bridged iodine(III) reagent $\mathbf{2 8}$ with PIFA. It was found that the reaction products 29 were obtained in higher yield using the bridged iodine(III) reagent compared to that using PIFA. Probably, the iodine-OCOCF 3 bond of the bridged compound $\mathbf{2 8}$ has a significant ionic character as

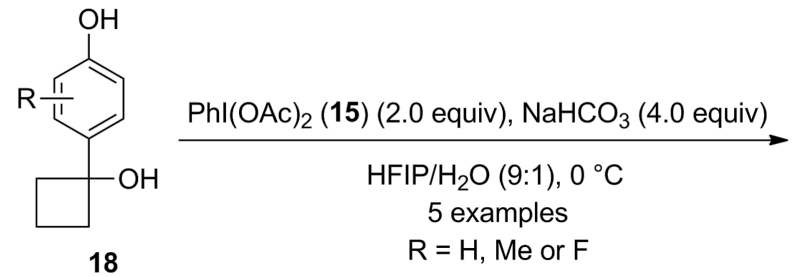<smiles>[R]C12C=CC(=O)C=CC1([R])OC(=O)CCC2</smiles>

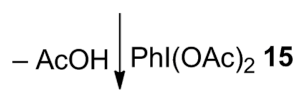
$\mathrm{R}=\mathrm{H}, \mathrm{Me}$ or $\mathrm{F}$

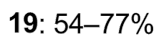

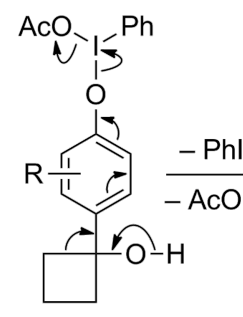

20

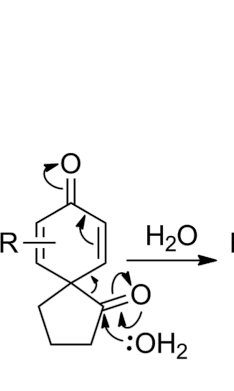

21

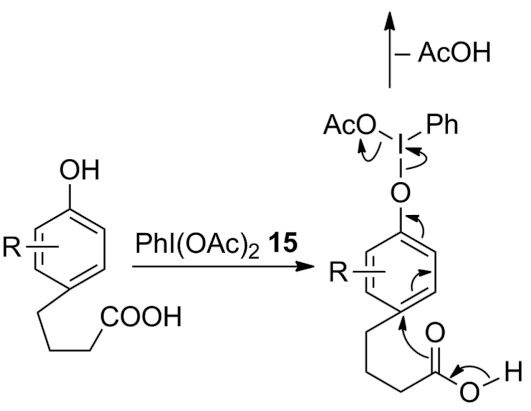

22
23 


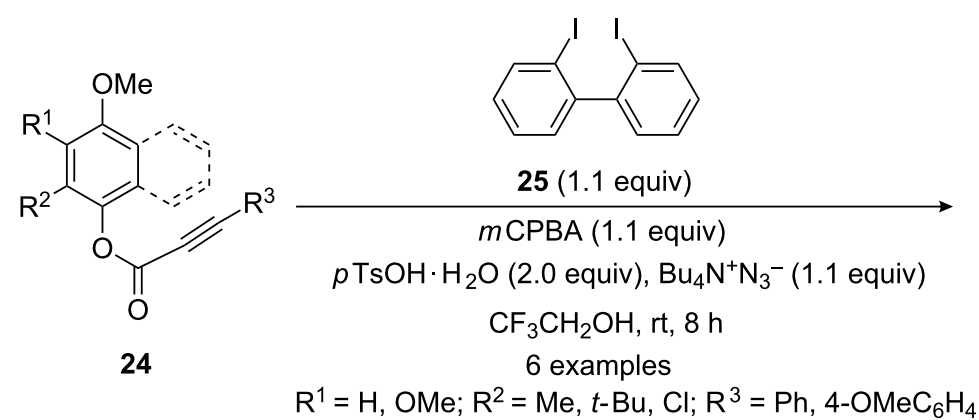

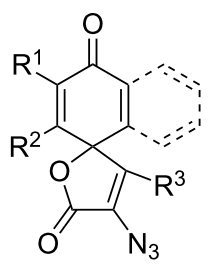

26: $86-99 \%$

Scheme 5: lodine(III)-mediated spirocyclization of aryl alkynes $\mathbf{2 4}$ to spirolactones $\mathbf{2 6}$ by the reaction with bis(iodoarene) 25 in the presence of $m$ CPBA.

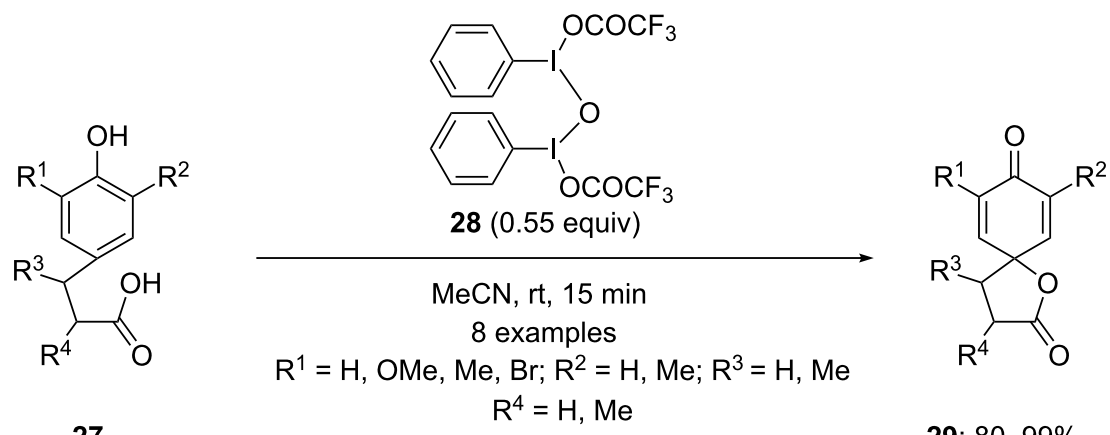

27

29: $80-99 \%$

Scheme 6: Bridged iodine(III)-mediated spirocyclization of phenols $\mathbf{2 7}$ to spirodienones 29.

the iodine-oxygen bond distance is larger than in PIFA which intends to make it more reactive than PIFA.

PIFA (31) is a more electrophilic iodine(III) reagent than PIDA (15) due to the presence of two trifluoroacetoxy groups. There are some approaches for the synthesis of spirocyclic compounds where PIFA (31) is used as electrophile.

Recently, Lewis and co-workers [73] reported the conversion of arnottin I (30) to its spirocyclic analogue arnottin II (32) by reaction with LiOH followed by PIFA (31). The spirocyclic product arnottin II (32) was isolated in 56\% yield
(Scheme 7). This approach is based on a tandem oxidative dearomatization process and will be quite useful for the conversion of functionalized benzocoumarins to spirocyclic lactones.

In 2015, Du and co-workers [74] reported a spirocyclization of diarylacetylenes to fused spiro polycyclic compounds through a hypervalent iodine-mediated cascade annulation reaction. In this reaction, the Lewis acid $\mathrm{BF}_{3} \cdot \mathrm{Et}_{2} \mathrm{O}$ acts as catalyst which activates the substrate. A further treatment with PIDA (15) forms the spirocyclic products through intramolecular cyclization.<smiles>COc1ccc2c(c1OC)c(=O)oc1c3cc4c(cc3ccc21)OCO4</smiles>

30

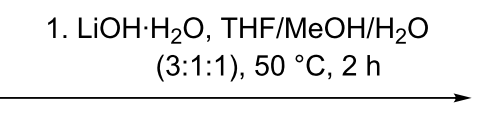

2. PIFA (31), HFIP, $0{ }^{\circ} \mathrm{C}, 12 \mathrm{~h}$

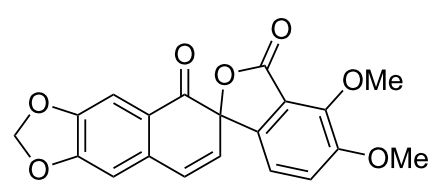

32: $56 \%$ 


\subsection{Using hypervalent iodine reagents as catalyst}

The hypervalent iodine-catalyzed synthesis of spirocylic compounds can be achieved either by using catalytic amounts of a hypervalent iodine species or by generation of a similar active catalytic species in situ by the oxidation of iodoarene using a terminal oxidant. More commonly, $m$-chloroperbenzoic acid $(m \mathrm{CPBA})$ and oxone are used as oxidant to generate the hypervalent iodine species in situ via oxidation of iodoarenes. In 2014, Singh and Wirth have compiled a review article where they have covered various aspects of hypervalent iodine catalyzed reactions [75].

In 2005, Kita and his research group investigated a hypervalent iodine-catalyzed spirocyclization reaction by generating the catalytic hypervalent iodine species via in situ oxidation of iodoarene using $m \mathrm{CPBA}$ as terminal oxidant [76]. In this report, $p$-substituted phenols 27 were cyclized to the corresponding spirolactones 29 using iodotoluene $\mathbf{3 3}$ as precatalyst, $m \mathrm{CPBA}$ as oxidant and TFA as an additive. The spirolactones 29 were isolated as reaction products in excellent yields (Scheme 8). Probably, the iodine(III) species was generated in situ as the active catalytic species that was playing the key role for the dearomatization of phenol. In addition, a similar reaction was also achieved by using various PIFA analogues as catalyst directly in the presence of 1.5 equivalents of $m$ CPBA. Since this report, several iodine(III)-catalyzed oxidative spirocyclization reactions have been successfully developed.

In 2009, Ishihara and co-workers [77] developed an oxylactonization of ketocarboxylic acid $\mathbf{3 4}$ to spirolactone $\mathbf{3 6}$ using
$10 \mathrm{~mol} \%$ of iodobenzene (35) as precatalyst, $20 \mathrm{~mol} \%$ of $\mathrm{TsOH} \cdot \mathrm{H}_{2} \mathrm{O}$ as additive and 1.8 equivalents of $m \mathrm{CPBA}$ as oxidant. The catalytic reaction was carried out in nitromethane at $50{ }^{\circ} \mathrm{C}$ for $23 \mathrm{~h}$ and spirolactone $\mathbf{3 6}$ was isolated in $74 \%$ yield (Scheme 9). It was noted that $20 \mathrm{~mol} \%$ of additive was essential to initiate the reaction efficiently. The reaction was quite slow when $10 \mathrm{~mol} \%$ of additive was used. Once again, iodine(III) species was generated in situ which was probably working as active catalytic species.

\subsection{Stereoselective synthesis of spirolactones}

Recently, Kita and co-workers [78] reported a new type of binaphthyl-based chiral iodine(III) species $\mathbf{3 8}$ and its efficient utilization in the spirocyclization of naphthols containing carboxylic acids. 1-Naphthol-2-propionic acids 37 were cyclized to corresponding spirolactone derivatives 39 using chiral-8,8'-diiodonaphthyl reagent $\mathbf{3 8}$ as precatalyst, $m$ CPBA as an oxidant in chloroform at low temperature. The reaction products 39 were isolated in good yields with more than $78 \%$ enantiomeric excess (Scheme 10). The active catalytic hypervalent iodine species was generated in situ by oxidation of optically active iodoarene 38 using $m \mathrm{CPBA}$ as an oxidant.

\subsection{Application of spirolactones in natural products synthesis}

In 2005, Wipf and Spencer [79] reported the first total synthesis of the Stemona alkaloid (-)-tuberostemonine (40). In this report, PIDA (15) was used as an electrophile for the synthesis of spirolactone $\mathbf{1 6}$ in $35 \%$ yield by the cyclization of L-tyrosine 14 in nitromethane at room temperature for $2.5 \mathrm{~h}$ (Scheme 11).<smiles>[R]c1cc(C([R])C([R])C(=O)O)cc([R])c1O</smiles>

27

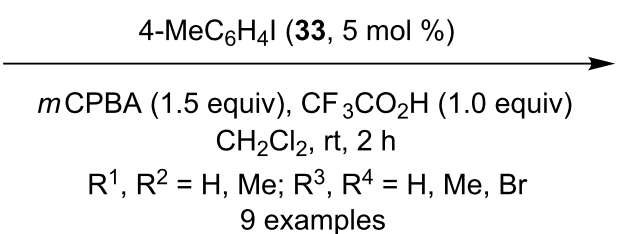

9 examples

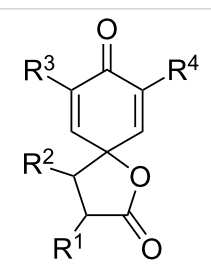

29: $66-91 \%$

Scheme 8: lodine(III)-catalyzed spirolactonization of $p$-substituted phenols $\mathbf{2 7}$ to spirolactones $\mathbf{2 9}$ using iodotoluene $\mathbf{3 3}$ as a precatalyst and $m$ CPBA as an oxidant.

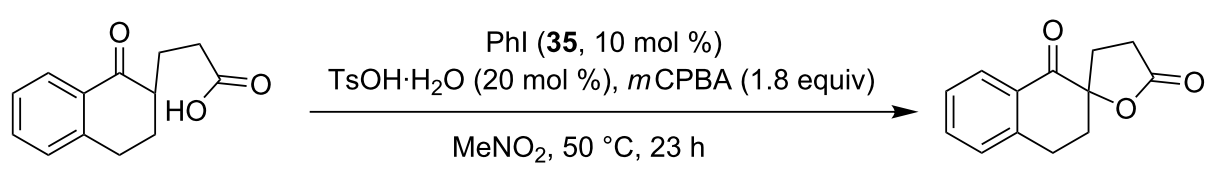




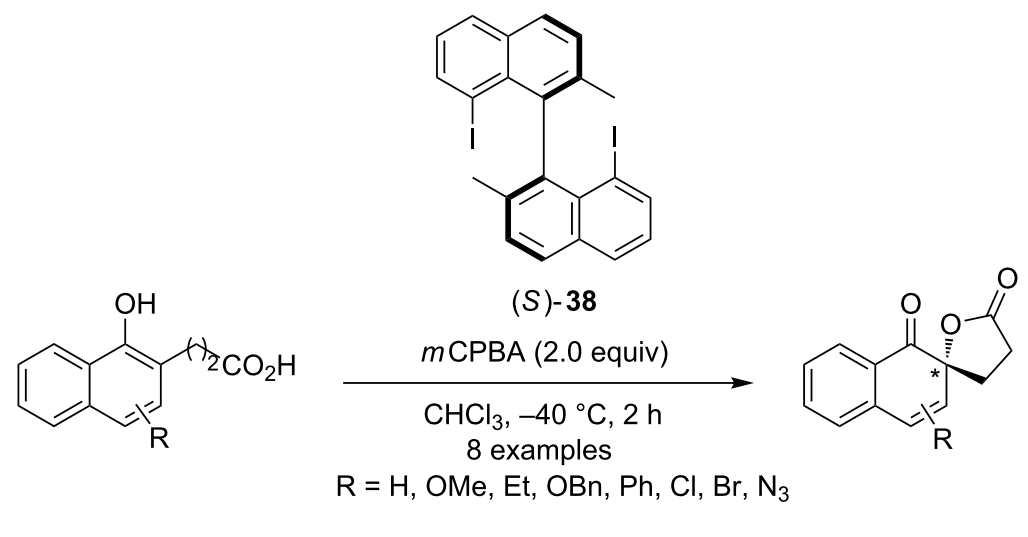

37

39: yield: $42-91 \%$; ee: $>78 \%$

Scheme 10: lodine(III)-mediated asymmetric oxidative spirocyclization of naphthyl acids $\mathbf{3 7}$ to naphthyl spirolactones $\mathbf{3 9}$ using chiral iodoarene $\mathbf{3 8}$ as precatalyst.<smiles>O=C([O-])N[C@@H](Cc1ccc(O)cc1)C(=O)O</smiles>

14<smiles>O=C1C=CC2(C=C1)CC(NC(=O)O)C(=O)O2</smiles>

16: $35 \%$

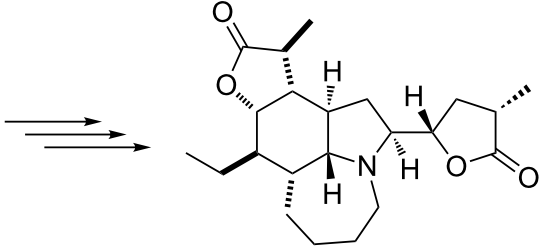

40: (-)-tuberostemonine

Scheme 11: Oxidative cyclization of L-tyrosine 14 to spirocyclic lactone 16 using PIDA (15).

Additionally, the synthesized spirocyclic precursor 16 was transfered to (-)-tuberostemonine (40) in three chemical steps.

\section{Synthesis of spirolactams}

\subsection{Using stoichiometric amounts of iodine(III)} reagents

In 1998, Ciufolini and co-workers [80] reported the oxidative cyclization of tyrosine derivatives to spirolactams using iodine(III) reagents. In this reaction, oxazoline derivatives 41 were cyclized to spirocyclic products 42 using PIDA (15) as an electrophile in trifluoroethanol at room temperature for 30 minutes. The desired products $\mathbf{4 2}$ were isolated in moderate yields (Scheme 12).
Additionally, the same research group [81] reported the oxidative cyclization of a phenolic substrate to a spirolactam using PIDA as electrophile. In this methodology, oxazoline $\mathbf{4 3}$ was cyclized to spirolactam 44 in 50\% yield using PIDA (15) in trifluoroethanol at room temperature (Scheme 13). Furthermore, spirolactam was used as intermediate in the synthesis of tricyclic compound $\mathbf{4 3}$ possessing a similar structure like that of the naturally occurring heterocyclic compound FR901483 [82].

Wardrop and co-workers [83] developed a new method for the preparation of 1 -azaspiranes 47 by treatment of $\alpha$ - and $\beta$-substituted 3-(methoxyphenyl)- $N$-methoxypropionamides 46 with [bis(trifluoroacetoxy)iodo]benzene (PIFA, 31) in dichloro-<smiles>[R]C1COC([R]([R])([H])c2ccc(O)cc2)=N1</smiles>

41

$$
\begin{aligned}
& \underset{\mathrm{CF}_{3} \mathrm{CH}_{2} \mathrm{OH}, \mathrm{rt}, 30 \mathrm{~min}}{\mathrm{Phl}(\mathrm{OAc})_{2}(15,1.1 \text { equiv) }} \\
& 5 \text { examples } \\
& \mathrm{R}^{1}=\mathrm{H}, \mathrm{NHTs} \text {, NHBOC } \\
& \mathrm{R}^{2}=\mathrm{H}, \mathrm{Bn} ; n=1,2
\end{aligned}
$$<smiles>[R]C(CO)N1C(=O)[C@]2([R1])C=CC=CC12[Y20]</smiles>

42: $17-47 \%$

Scheme 12: Oxidative cyclization of oxazoline derivatives 41 to spirolactams 42 using PIDA (15). 


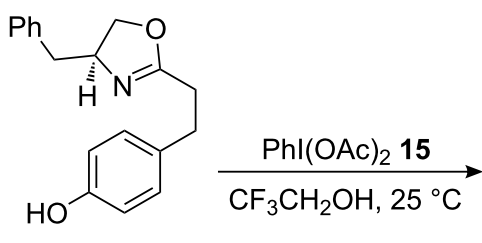

43

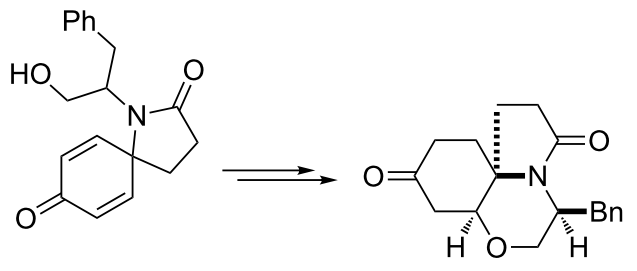

44: $50 \%$

45

Scheme 13: Oxidative cyclization of oxazoline 43 to spirolactam 44 using PIDA 15 as oxidant.

methane (Scheme 14). The reactions were carried out at low temperature and spirolactams $\mathbf{4 7}$ were achieved in high yields with up to $96 \%$ enantiomeric excess. Furthermore, these compounds have been employed as important synthetic intermediates for the construction of biologically active molecules such as histrionicotoxins and the cytotoxic marine alkaloid fasicularin [84].

In 2010, Honda [85] reported the synthesis of isoquinoline alkaloids possessing spirocyclic framework using PIDA (15) as an electrophile in hexafluroisopropanol solvent. The $p$-substituted phenolic compound $\mathbf{4 8}$ was used as starting material for the construction of spirolactam 49 in $69 \%$ yield (Scheme 15). This is an important intermediate in the synthesis of various naturally occurring alkaloids such as TAN1251A, TAN1251C and TAN1251D [86].

Wardrop and Burge [87] reported a iodine(III)-mediated oxidative spirocyclization of hydroxamates $\mathbf{5 0}$. The azaspirans $\mathbf{5 1}$ containing quaternary carbon centers were synthesized in good to excellent yields on treating substrates $\mathbf{5 0}$ with PIFA (31) in dichloromethane/methanol (1:1, Scheme 16). The reaction products (spirolactams 51) were obtained as inseparable mixture of anti- and syn-diastereomers.

Haroutounian and co-workers [88] investigated a PIFA-mediated synthesis of spirocyclic lactam $\mathbf{5 4}$ as side product by treating substrate 52 with 1.5 equivalents of PIFA (31) in presence of 3.0 equivalents of TFA as an additive in dichloro-

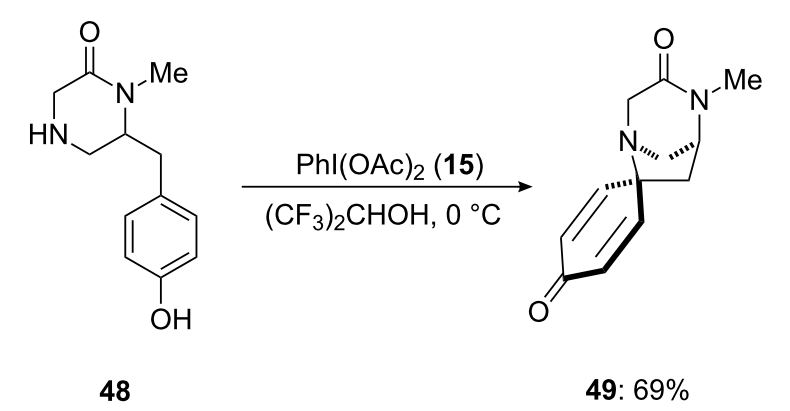

Scheme 15: Synthesis of spirolactam 49 from phenolic enamide 48 using PIDA (15).

methane (Scheme 17). The fused tricyclic compound $\mathbf{5 3}$ was obtained as major product in $55 \%$ yield along with the spiro compound $\mathbf{5 4}$ as a minor product in $8 \%$ yield.

In 2009, Zhang and co-workers [89] reported an efficient method for the synthesis of spiro $\beta$-lactams via oxidative dearomatization reactions. In this report, the synthesis of spiro $\beta$-lactams 56 were achieved successfully by the oxidative cyclization of $p$-substituted phenols 55 using PIDA (15) as an electrophile and copper(II) sulfate pentahydrate as an additive in the presence of DMAP base. The spirocyclization reactions were performed in $\mathrm{MeOH}$ for $2 \mathrm{~h}$ at $0{ }^{\circ} \mathrm{C}$ and spirocyclic products 56 were isolated in good yields (Scheme 18). Additionally, fused bicyclic compounds $\mathbf{5 7}$ were also observed in few reactions in traces. The structure of the spiro $\beta$-lactam was confirmed by single crystal X-ray crystallography.<smiles>[R]c1cc(OC)ccc1C([R])C([R])C(=O)NOC</smiles>

46

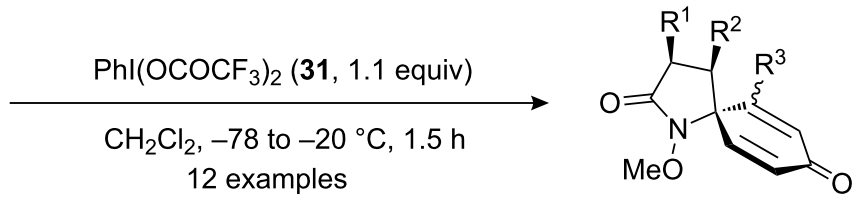

$\mathrm{R}^{1}=\mathrm{H}, \mathrm{Me}, n-\mathrm{Bu}, \mathrm{OTIPS}, \mathrm{Bn}$ $\mathrm{R}^{2}=\mathrm{H}, \mathrm{Me}, n-\mathrm{Bn} ; \mathrm{R}^{3}=\mathrm{Me}, \mathrm{iPr}, \mathrm{OMe}$

47: yield: $68-98 \%$; ee: $>96 \%$ 
<smiles>[R]ONC(=O)C([R])Cc1ccc(O[W])cc1OC</smiles>

50

\author{
PIFA (31, 1.2 equiv) \\ $\mathrm{CH}_{2} \mathrm{Cl}_{2} / \mathrm{MeOH}(1: 1),-78$ to $-15^{\circ} \mathrm{C}, 1.5 \mathrm{~h}$ \\ 15 examples \\ $n=0,1,2 ; \mathrm{R}^{1}=\mathrm{Me}, \mathrm{Bn}$ \\ $\mathrm{R}^{2}=\mathrm{H}, \mathrm{Me}, t-\mathrm{Bu}, \mathrm{Bn}, \mathrm{Ph}$, OTIPS, NHBz
}<smiles>[R]C1C[C@@]2(OC)C1=CC(=O)C=CC2OC</smiles>

51: $53-98 \%$

Scheme 16: lodine(III)-mediated spirocyclization of alkyl hydroxamates $\mathbf{5 0}$ to spirolactams $\mathbf{5 1}$ using stoichiometric amount of PIFA (31).<smiles></smiles>

52
$\mathrm{Phl}\left(\mathrm{OCOCF}_{3}\right)_{2}(31,1.5$ equiv $)$

TFA (3.0 equiv)

$\mathrm{CH}_{2} \mathrm{Cl}_{2},-20^{\circ} \mathrm{C}, 1 \mathrm{~h}$<smiles>COc1ccc2c3nn(-c4ccccc4)cc3c(=O)n(OC)c2c1</smiles>

53: $55 \%$<smiles></smiles>

54: $8 \%$

Scheme 17: PIFA-mediated cyclization of substrate 52 to spirocyclic product 54 .<smiles></smiles>

55

\author{
$\mathrm{Phl}\left(\mathrm{OCOCH}_{3}\right)_{2}(15,1.2$ equiv) \\ $\mathrm{CuSO}_{4} \cdot 5 \mathrm{H}_{2} \mathrm{O}$ (1.0 equiv) \\ DMAP, $\mathrm{MeOH}, 0^{\circ} \mathrm{C}, 2 \mathrm{~h}$ \\ overal yield $76-92 \%$ \\ 10 examples \\ $\mathrm{R}=\mathrm{Me}, \mathrm{NO}_{2}, \mathrm{OMe}$
}

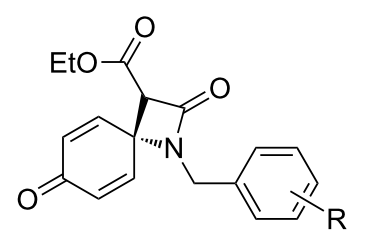

56<smiles>[R]c1ccc(CN2C(=O)C(C(=O)OCC)[C@H]3CC(=O)C=CC32OC)cc1</smiles>

57

Scheme 18: Synthesis of spiro $\beta$-lactams 56 by oxidative coupling reaction of $p$-substituted phenols 55 using $\mathrm{PIDA}_{(15)}$ and $\mathrm{CuSO}_{4} \cdot 5 \mathrm{H}_{2} \mathrm{O}$ in the presence of base in methanol.

Dong and co-workers [90] developed a novel way for the synthesis of five membered spiro pyrazolin-5-ones using amide and amine-containing precursors. Herein, five-membered azaheterocyclic derivatives were synthesized efficiently in presence of PIFA and with TFA as an additive.

Furthermore, Kita and his research group [71] displayed a method for the cyclization of alkyne derivative $\mathbf{5 8}$ to spirolactam 59 by an in situ-generated active hypervalent iodine species. In this method, para-substituted amide $\mathbf{5 8}$ was cyclized to the corresponding spirolactam $\mathbf{5 9}$ in $92 \%$ yield using a stoichiometric amount of bis(iodoarene) 25 with the terminal oxidant $m$ CPBA in the presence of $\mathrm{TsOH} \cdot \mathrm{H}_{2} \mathrm{O}$ in TFE (Scheme 19).
In 2012, Zhao and co-workers [91] developed a new approach for the construction of spirooxindoles $\mathbf{6 1}$ through tandem cascade oxidation of substituted anilides $\mathbf{6 0}$. In this methodology, anilide derivatives $\mathbf{6 0}$ were reacted with [bis(trifluoroacetoxy)iodo]benzene (31, PIFA) in TFE at room temperature to afford functionalized lactams 61 in good yields (Scheme 20). Various electron-donating and withdrawing groups at the phenyl ring in anilides were successfully tolerated.

Furthermore, Sunoj and Sreenithya [92] developed a metal-free approach for the synthesis of 1,1'-dimethyl-3,3'-spirobi[indoline]-2,2'-dione (61) from $N^{1}, N^{3}$-dimethyl- $N^{1}, N^{3}$-diphenylmalonamide (60) using PIFA (31) in trifluoroethanol at room temperature. The spirolactam $\mathbf{6 1}$ was isolated in $75 \%$ yield 
<smiles>COc1ccc(NC(=O)C#Cc2ccccc2)cc1</smiles>

58

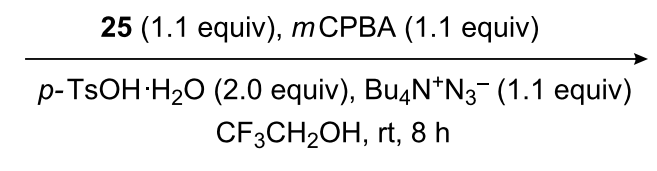

$\mathrm{CF}_{3} \mathrm{CH}_{2} \mathrm{OH}, \mathrm{rt}, 8 \mathrm{~h}$<smiles>NC1=C(c2ccccc2)C2(C=CC(=O)C=C2)NC1=O</smiles>

59: $92 \%$

Scheme 19: lodine(III)-mediated spirocyclization of para-substituted amide $\mathbf{5 8}$ to spirolactam $\mathbf{5 9}$ by the reaction with bis(iodoarene) 25 in the presence of $m C P B A$.<smiles>[R]c1ccc(N([R2])C(=O)CC(=O)N([R2])c2ccc([R])cc2)cc1</smiles>

60

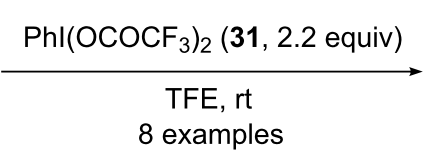

$\mathrm{R}^{1}=\mathrm{H}, \mathrm{Cl} ; \mathrm{R}^{2}=\mathrm{Me}, \mathrm{Bn}, \mathrm{Ph}$ $\mathrm{R}^{3}=\mathrm{H}, \mathrm{Cl}, \mathrm{Me}, \mathrm{NO}_{2} ; \mathrm{R}^{4}=\mathrm{Me}, \mathrm{Bn}, \mathrm{Ph}$<smiles>[R]c1ccc2c(c1)C1(C(=O)N2[R])C(=O)N([R])c2ccc([R])cc21</smiles>

61: $40-75 \%$

Scheme 20: lodine(III)-mediated synthesis of spirolactams 61 from anilide derivatives 60 .

(Scheme 21). According to the proposed mechanistic pathway, the reaction was initiated with formation of an intermediate $\mathbf{6 3}$ by the attack of the carbonyl oxygen to electrophilic iodine(III) reagent 31 which could be rearranged to compound 64. Finally, the acetate anion attacks the $\beta$-hydrogen of $\mathbf{6 4}$ to form spirolactam product $\mathbf{6 1}$.

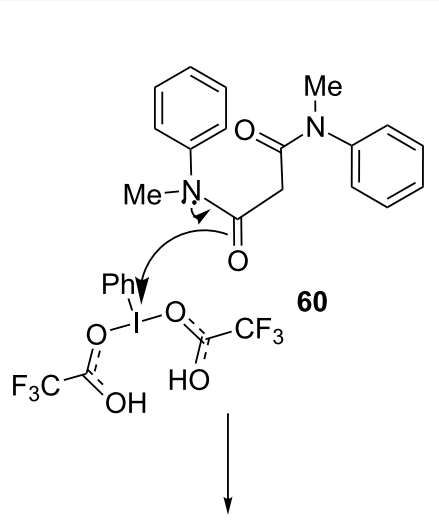

$\operatorname{Phl}\left(\mathrm{OCOCF}_{3}\right)_{2}(31,2.2$ equiv $)$

TFE, rt<smiles>CN1C(=O)C2(C(=O)N(C)c3ccccc32)c2ccccc21</smiles>

61: $75 \%$ $\operatorname{Phl}\left(\mathrm{OCOCF}_{3}\right)_{2} 31$<smiles>C/N=C(\OCC(=O)OC(=O)C(F)(F)F)[C@@H](C(=O)N(C)c1ccccc1)c1ccccc1</smiles>

62<smiles>CN(C(=O)C(I)C(=O)N(C)c1ccccc1)C(=O)C(OC(=O)C(F)(F)F)(c1ccccc1)c1ccccc1</smiles>

63
64

Scheme 21: PIFA-mediated oxidative cyclization of anilide 60 to bis-spirobisoxindole 61. 
In 2014, Xu and Abdellaoui [93] reported a nucleophilic intramolecular cyclization of phenylacetamides $\mathbf{6 5}$ to spirocyclic lactams 66 via iodine(III)-mediated spirocarbocyclizations. In literature, there are limited methods available for the synthesis of spiro- $\beta$-lactam-3-carbonitrile which is widely used as an antibiotic [94]. In this methodology, $N$-( $p$-hydroxyphenyl)cyanoacetamides 65 were cyclized to corresponding 4 -spiro- $\beta$-lactam3 -carbonitriles 66 in useful yields using PIDA (15) as an electrophile in the presence of $\mathrm{KOH}$ as base in anhydrous ethanol at room temperature (Scheme 22).

In 2014, Fan and co-workers [95] investigated an efficient approach for the synthesis of a spirocyclic-skeleton-containing dieniminium moiety. Herein, arylamines 67 were cyclized to spirocyclic dieniminium salts 68 using PIFA (31) as an electrophilic species in nitromethane (Scheme 23). All the reactions were completed within a minute and desired lactams were iso- lated in good yields. The presence of electron-withdrawing groups at the aromatic ring shows a negative effect on the yield while the presence of electron-enriched groups afforded the products $\mathbf{6 8}$ in high yields.

In addition, Zhu and co-workers [96] developed another hypervalent iodine-mediated intermolecular spirocarbocyclization approach for synthesis of spirolactam. In this approach, $\mathrm{N}$-methoxybenzamide 69 and diphenylacetylene (70) were treated in presence of PIFA (31) in dichloromethane to corresponding spirodienone compound 71 in $48 \%$ yield (Scheme 24). Additionally, trifluoroacetic acid (TFA) was used as an additive in the reaction.

In 2015, Wang's group [97] reported an iodine(III)-mediated approach for the intermolecular spirocyclization of amides $\mathbf{7 2}$ with sulfonylhydrazides $\mathbf{7 3}$ to spirolactams $\mathbf{7 5}$. In this method,<smiles>[R]CN(C(=O)CC#N)c1ccc(O)cc1</smiles><smiles>[R]CN1C(=O)C(C#N)C12C=CC(=O)C=C2</smiles>

66: $57-95 \%$

Scheme 22: PIDA-mediated spirocyclization of phenylacetamides 65 to spirocyclic lactams 66 .<smiles>[R]c1cccc(N([R])C(=O)O)c1C(C)=O</smiles>

67

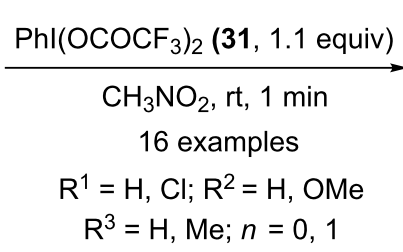

$\mathrm{R}^{3}=\mathrm{H}, \mathrm{Me} ; n=0,1$

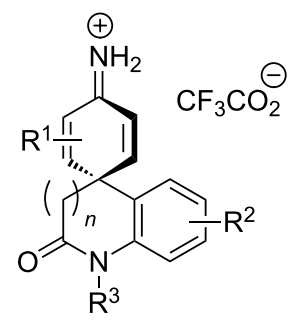

68: $24-91 \%$

Scheme 23: Oxidative dearomatization of arylamines 67 with PIFA (31) to give dieniminium salts 68 .<smiles>CONC(=O)c1ccc(OC)cc1</smiles> 
functionalized amides $\mathbf{7 2}$ containing an alkyne moiety and sulfonylhydrazides $\mathbf{7 3}$ undergo intermolecular spirocyclization in presence of $\mathrm{I}_{2} \mathrm{O}_{5} /$ TBHP oxidative system to give the sulfonated spirolactams $\mathbf{7 5}$ in high yields (Scheme 25). This oxidative system found to be more efficient and could sustain the presence of diverse functional groups. The structure of $\mathbf{7 5}$ was confirmed by single crystal X-ray crystallography.

\subsection{Using hypervalent iodine reagents as catalysts}

In 2007, Kita and co-workers [98] investigated the first iodoarene-catalyzed spirocyclization of functionalized amides $\mathbf{7 6}$ to spirocyclic systems $\mathbf{7 7}$ by carbon-nitrogen bond formation using $10 \mathrm{~mol} \%$ of iodotoluene $\mathbf{3 3}$ as precatalyst, 1.0 equivalent of $\mathrm{CF}_{3} \mathrm{COOH}$ as an additive and $m \mathrm{CPBA}$ as terminal oxidant in trifluoroethanol (Scheme 26). The spirocyclic compounds 77 were isolated in high yields. The cyclization reaction was probably initiated by in situ generated active iodine(III) species by the oxidation of iodotoluene $\mathbf{3 3}$ in the presence of $m$ CPBA.

In 2010, Zhu's research group [99] achieved a Pd-catalyzed synthesis of spirolactams $\mathbf{8 0}$ by the cyclization of functionalized amides 78 using $10 \mathrm{~mol} \% \mathrm{PdCl}_{2}$ (79) in presence of $\mathrm{PhI}(\mathrm{OAc})_{2}(\mathbf{1 5})$ in acetonitrile solvent at $80{ }^{\circ} \mathrm{C}$. The spirocyclic products $\mathbf{8 0}$ were obtained in moderate yields (Scheme 27). It was observed that the introduction of electron-donating group at para-position in substrates $\mathbf{7 8}$ gave the desired products in good yields whereas introduction of strong electron with-<smiles>[R]C#CC(=O)N([R])c1cc[R1]cc1</smiles>

72<smiles>[R]S(=O)(=O)NN</smiles>

73
$\mathrm{I}_{2} \mathrm{O}_{5}(\mathbf{7 4}, 1.0$ equiv), TBHP (3.0 equiv)

1,4-dioxane, $80^{\circ} \mathrm{C}, 12-30 \mathrm{~h}$ 22 examples

$\mathrm{R}^{1}=\mathrm{H}, \mathrm{Et}, \mathrm{F}, \mathrm{Cl}, \mathrm{Br}, \mathrm{I}, \mathrm{Me} ; \mathrm{R}^{2}=\mathrm{H}, \mathrm{OAc}, \mathrm{Me}$ $\mathrm{R}^{3}=\mathrm{Me}, \mathrm{Ph}, 4-\mathrm{FC}_{6} \mathrm{H}_{4}, 4-\mathrm{OMeC}_{6} \mathrm{H}_{4}$, 4- $\mathrm{MeC}_{6} \mathrm{H}_{4}, 4-\mathrm{ClC}_{6} \mathrm{H}_{4}, 4-\mathrm{BrC}_{6} \mathrm{H}_{4}, 4-\mathrm{FC}_{6} \mathrm{H}_{4}$ $\mathrm{R}^{4}=\mathrm{Ph}, 4-\mathrm{MeC}_{6} \mathrm{H}_{4}, 4-\mathrm{OMeC}_{6} \mathrm{H}_{4}, 4-\mathrm{ClC}_{6} \mathrm{H}_{4}$, 4- $\mathrm{BrC}_{6} \mathrm{H}_{4}, 4-\mathrm{CF}_{3} \mathrm{C}_{6} \mathrm{H}_{4}$

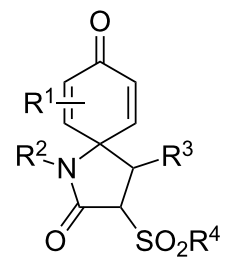

75: $60-89 \%$

Scheme 25: Synthesis of spiroxyindole 75 using $\mathrm{I}_{2} \mathrm{O}_{5} /$ TBHP oxidative system.<smiles>[R]c1c(OC)ccc([Y]([H])([H])C(=O)NOC)c1[R]</smiles>

76

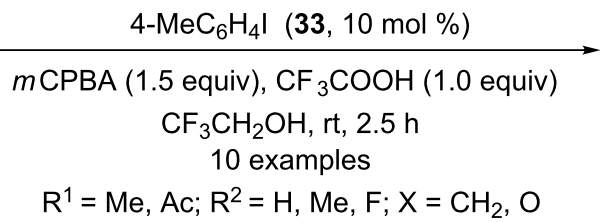

$n=0,1$

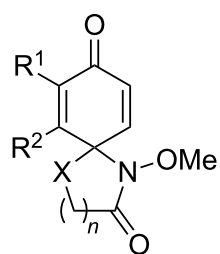

77: $53-97 \%$

Scheme 26: lodine(III)-catalyzed spirolactonization of functionalized amides 76 to spirolactones 77 using iodotoluene 33 as a precatalyst and $m$ CPBA as an oxidant.

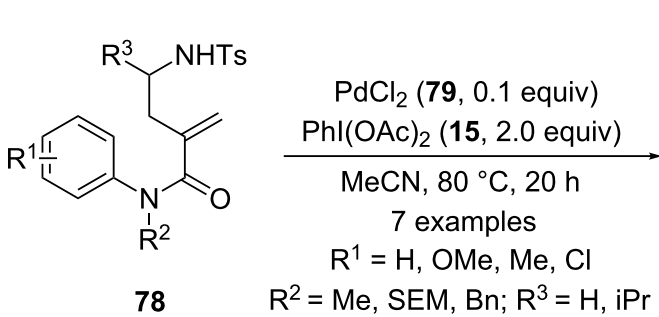<smiles>[R]C1C[C@@]2(CN([AsH3-])C(=O)N2[R])C2=C1C=C[R1]C=C2</smiles>

80: $37-58 \%$ 
drawing groups resulted in a decrease in the yield of spirocyclic products.

Kita and co-workers [100] developed another catalytic approach for the cyclization of amides $\mathbf{7 6}$ to spirolactams $\mathbf{7 7}$. In this approach, $2 \mathrm{~mol} \%$ of bis(iodoarene) $\mathbf{8 1}$ was used as precatalyst and peracetic acid (PAA) as an oxidant instead of $m$ CPBA, which plays an important role in generation of active iodine(III) species. The bis(iodoarene) $\mathbf{8 1}$ was oxidized to a unique $\mu$-oxo-bridged hypervalent iodine(III) species in situ, wherein PAA is used as extremely green oxidant which releases non-toxic co-products (Scheme 28).

In 2011, Yu and co-workers [101] developed an intramolecular lactonization of $p$-substituted phenols $\mathbf{8 2}$ to spirooxindoles $\mathbf{8 3}$ using $10 \mathrm{~mol} \%$ of iodobenzene (35) as precatalyst, $m \mathrm{CPBA}$ as an external oxidant and TFA as additive. All the catalytic reactions were performed in dichloromethane and spirolactams $\mathbf{8 3}$ were isolated in good to excellent yields (Scheme 29). It was noted that $m \mathrm{CPBA} / \mathrm{TFA}$ combination did not work well for some transformations and it was replaced with oxidant urea $\cdot \mathrm{H}_{2} \mathrm{O}_{2}$ and TFAA as an additive.

\subsection{Stereoselective synthesis of spirolactams}

Gong and co-workers [102] efficiently cyclized 1-hydroxy- $N$ aryl-2-naphthamides $\mathbf{8 4}$ to corresponding spirolactam derivatives 86 using chiral iodoarene $\mathbf{8 5}$ as precatalyst, $m \mathrm{CPBA}$ as an oxidant and TFE as an additive. The presence of 10.0 equivalents of $\mathrm{H}_{2} \mathrm{O}$ was required to get the reaction products in high yields with up to $92 \%$ ee (Scheme 30 ). The chiral hypervalent$\lambda^{3}$-iodanes were generated in situ by the oxidation of the chiral $C_{2}$-symmetric iodoarene $\mathbf{8 5}$ that was playing the key role for the oxidative spirocyclization of phenols.

In addition, $N$-methyl- $N$-(2-naphthyl)-2-naphthamides 87 were also cyclized to corresponding spiro compounds $\mathbf{8 8}$ in high yields and with upto $84 \%$ enantiomeric excess (Scheme 31 ). Furthermore, the absolute configuration of $\mathbf{8 8}$ was assigned by its single crystal X-ray analysis.

\subsection{Application of spirolactams in natural product synthesis}

In 2001, Ciufolini and co-workers [103] employed PIDA (15) as an electrophile during the synthesis of naturally occurring tricyclic azaspirane derivative TAN1251C. In this report,<smiles>[R]c1c(CCC(=O)NOC)ccc(OC)c1[R]</smiles>

76

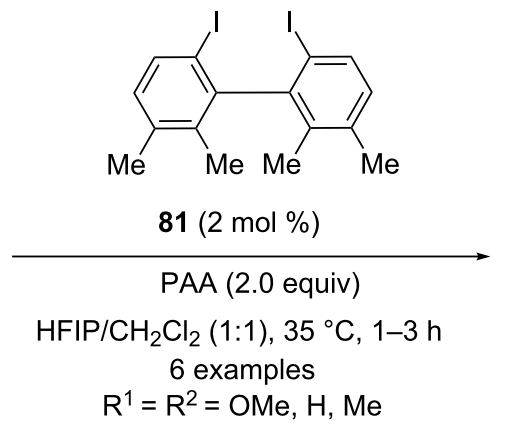

$R^{1}=R^{2}=\mathrm{OMe}, \mathrm{H}, \mathrm{Me}$

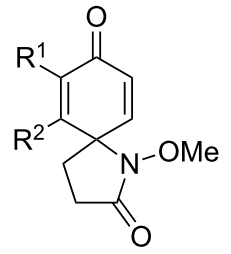

77: $45-78 \%$

Scheme 28: lodine(III)-catalyzed spiroaminocyclization of amides $\mathbf{7 6}$ to spirolactam 77 using bis(iodoarene) 81 as a precatalyst in the presence of PAA.<smiles>[R]N(C(=O)c1ccc(O)cc1)c1cc#[R1]cc1</smiles>

82

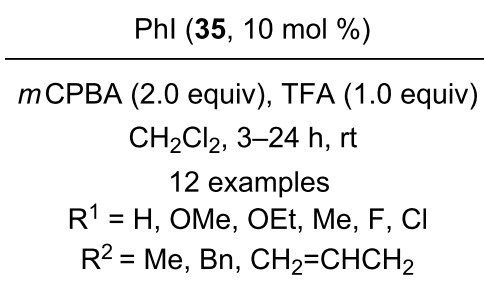

$\mathrm{Phl}(35,10 \mathrm{~mol} \%)$ $m$ CPBA (2.0 equiv), TFA (1.0 equiv) $\mathrm{CH}_{2} \mathrm{Cl}_{2}, 3-24 \mathrm{~h}, \mathrm{rt}$ 12 examples $\mathrm{R}^{1}=\mathrm{H}, \mathrm{OMe}, \mathrm{OEt}, \mathrm{Me}, \mathrm{F}, \mathrm{Cl}$ $\mathrm{R}^{2}=\mathrm{Me}, \mathrm{Bn}, \mathrm{CH}_{2}=\mathrm{CHCH}_{2}$<smiles>[R]N1C(=O)C2(C=CC(=O)C=C2)c2cc[R1]cc21</smiles>

83: $52-90 \%$ 


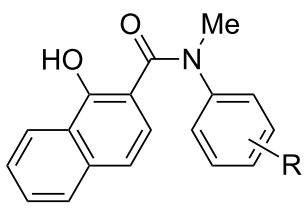

84

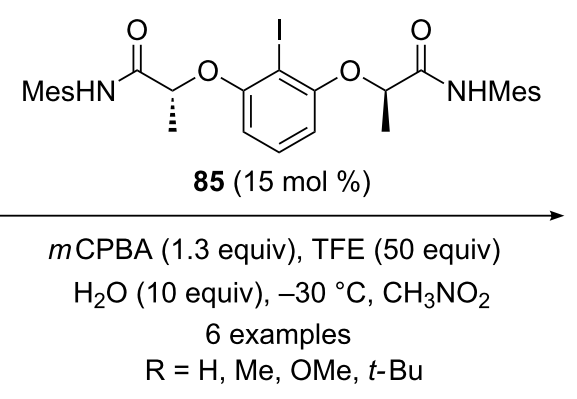

86

yield: $42-61 \%$; ee: $<92 \%$

Scheme 30: lodine(III)-mediated asymmetric oxidative spirocyclization of phenols $\mathbf{8 4}$ to spirolactams 86 using chiral iodoarene 85 as precatalyst.<smiles></smiles>

87

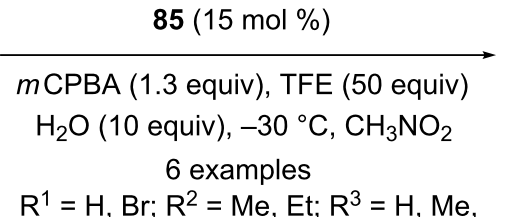

$\mathrm{OMe}, \mathrm{OBn}$<smiles></smiles>

88

yield: $65-80 \%$; ee: $<84 \%$

Scheme 31: lodine(III)-catalyzed asymmetric oxidative spirocyclization of $\mathrm{N}$-aryl naphthamides 87 to spirocyclic compounds 88 using chiral iodoarene $\mathbf{8 5}$ as precatalyst.

phenolic 3-arylpropionamide $\mathbf{8 9}$ was cyclized to spirolactam $\mathbf{9 0}$ in $41 \%$ yield using PIDA (15) as an electrophile in the presence of $\mathrm{NaHCO}_{3}$ in trifluoroethanol (TFE) at room temperature followed by addition of acetic anhydride and pyridine in the pres- ence of 10 mol \% DMAP (Scheme 32). In addition, spirocyclic product 90 was used as key precursor in the synthesis of naturally occurring tricyclic azaspirane derivative TAN1251C 91 in a sequence of steps.

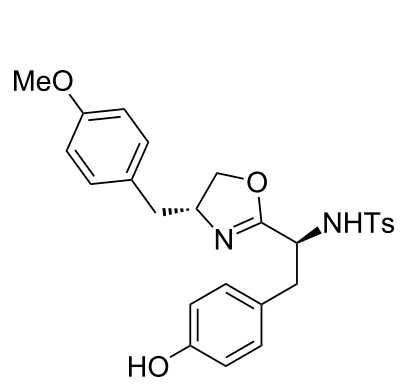

89

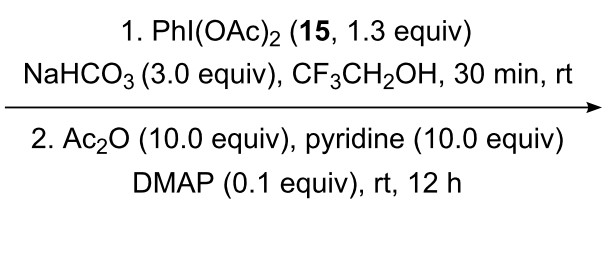

1. $\mathrm{Phl}(\mathrm{OAc})_{2}$ (15, 1.3 equiv)

2. $\mathrm{Ac}_{2} \mathrm{O}$ (10.0 equiv), pyridine (10.0 equiv)

DMAP ( 0.1 equiv), rt, $12 \mathrm{~h}$

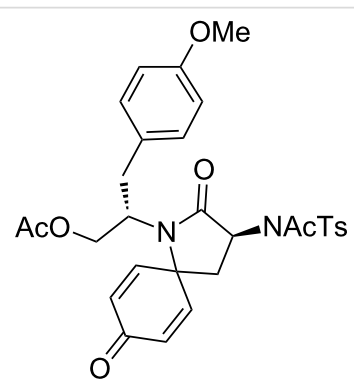

90: $41 \%$

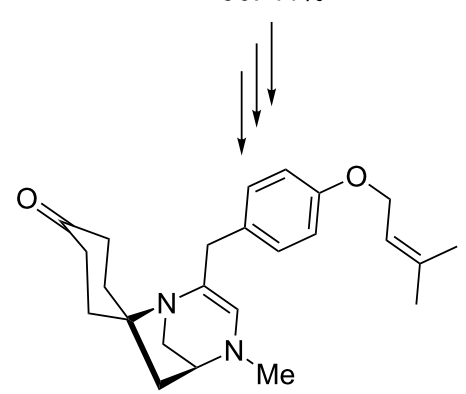

91: TAN1251C 
Furthermore, PIDA (15) was used as an electrophile during the synthesis of biologically active molecule FR901483 by the same research group [104]. In this report, spirocyclic oxazoline 93 was prepared by starting from para-substituted phenolic compound 92 under the reaction conditions mentioned in Scheme 32 (Scheme 33).

In 2002, Honda and co-workers [105] reported the synthesis of naturally occurring (-)-TAN1251A (95) employing an oxidation of phenols via an dearomatization process. In this report, para-substituted phenolic compound $\mathbf{4 8}$ was cyclized to spirocyclic lactam 49 using PIDA (15) as an electrophile. The spirocyclic compound 49 was achieved in $69 \%$ yield (Scheme 34 ). Additionally, synthesized spirocyclic compound 49 was converted to natural product $\mathbf{9 5}$ in few chemical steps.

\section{Synthesis of spirocarbocycles}

\subsection{Using stoichiometric amounts of iodine(III) reagents}

Furthermore, $O$-silylated phenolic compound 96 was spirocyclized to spirocarbocyclic compound 97 in 95\% yield using bridged iodine(III) reagent $\mathbf{2 8}$ as an electrophile and trifluoroethanol (TFE) as the solvent at room temperature (Scheme 35). Compound 97 was further used as substrate for the synthesis of discorhabdin alkaloids [106,107].

In 1996, Kita and co-workers [108] developed an intramolecular cyclization of ortho-substituted phenols 98 to aza-spirocarbocyclic compounds 101 via hypervalent iodine-mediated spirocarbocyclization reactions using $\mathbf{3 1}$ as an electrophile. In this methodology, ortho-substituted phenolic derivatives 98 were<smiles>CN[C@H](Cc1ccc(O)cc1)C1=N[C@H](CN=[W])CO1</smiles>

92
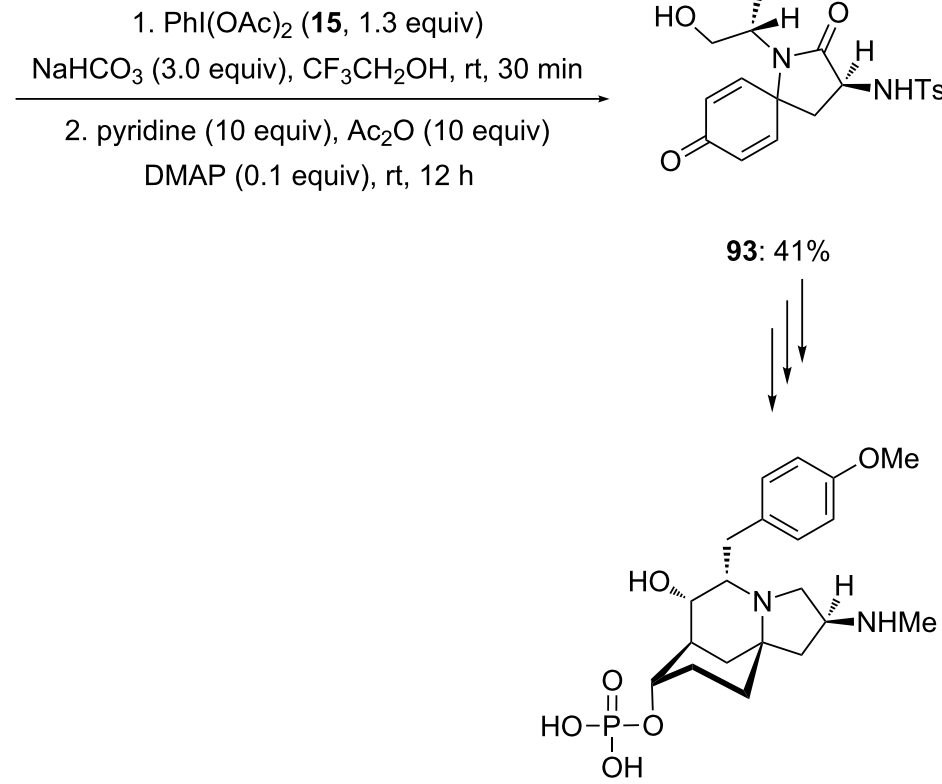

94: FR901483<smiles>CN1C(=O)CNCC1Cc1ccc(O)cc1</smiles>

48<smiles>CC#CC</smiles>

49: $69 \%$<smiles>CC(C)=CCOc1ccc(/C=C2/CN3CC4CC(=O)CCC(C4)N3C2)cc1</smiles>

95: (-)-TAN1251A 
<smiles>CCCCOc1ccc(CCNC(=O)C2=CC(=O)c3ccccc3C2=O)cc1</smiles>

96

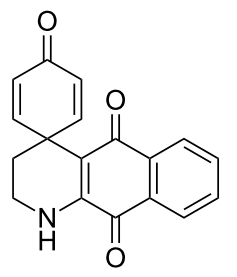

97: $95 \%$
Scheme 35: Bridged iodine(III)-mediated spirocyclization of O-silylated phenolic compound $\mathbf{9 6}$ in the synthesis of spirodienone $\mathbf{9 7 .}$

treated with stoichiometric amounts of PIFA (31) in trifluoroethanol at room temperature for $0.5 \mathrm{~h}$ to afford spirocyclic compounds $\mathbf{1 0 1}$ in good yields (Scheme 36).
Like PIDA and PIFA, Koser reagents are other iodine(III) reagents known to behave as electrophiles. In 2000, Spyroudis and co-workers [109] reported the spirocyclization of parasubstituted phenols $\mathbf{1 0 2}$ to corresponding spirocarbocyclic derivatives 104 via dearomatization process using Koser reagent. In this reaction, substrates $\mathbf{1 0 2}$ were reacted with a stoichiometric amount of [(hydroxy)(tosyloxy)iodo]benzene (103) in dichloromethane at $0{ }^{\circ} \mathrm{C}$. The spirocyclic products 104 were obtained in poor yields (Scheme 37).

Furthermore, Kita and his research group [71] reported the synthesis of spirocarbocyclic compounds $\mathbf{1 0 6}$ from arylalkynes $\mathbf{1 0 5}$ using a hypervalent iodine reagent generated in situ by the oxidation of bis(iodoarene) 25 in the presence of $m \mathrm{CPBA}$ as an terminal oxidant (Scheme 38).<smiles>[R][Y]1=C2C(=O)C=C(NCCc3ccccc3[R])C(=O)C2=[Y]([R])C1[R]</smiles>

98<smiles>[R]c1[X]c2c([R])c([R])[X]c3c(=O)c4c(c(=O)c=3c2[nH]1)CC41C=CC=CC1=O</smiles>

$101(30-76 \%)$

\section{$\underset{\mathrm{CF}_{3} \mathrm{CH}_{2} \mathrm{OH}, \mathrm{rt}, 0.5 \mathrm{~h}}{\mathrm{PIFA}(31,1.2 \text { equiv) }}$ \\ 8 examples \\ $\mathrm{R}^{1}=\mathrm{H}, \mathrm{TMS}$, TBDMS \\ $\mathrm{R}^{2}=\mathrm{H}, \mathrm{Me} ; \mathrm{X}=\mathrm{Y}=\mathrm{C}, \mathrm{N}$}

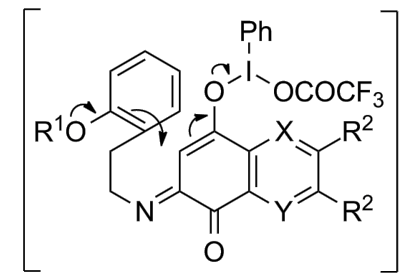

99

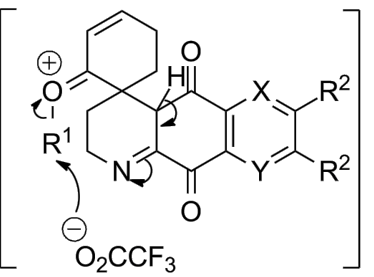

100

Scheme 36: PIFA-mediated approach for the spirocyclization of ortho-substituted phenols 98 to aza-spirocarbocyclic products 101.<smiles>[R]/C(=C/C(C)=O)NCCc1ccc(O)cc1</smiles>

$\mathrm{Phl}(\mathrm{OH})(\mathrm{OTs}) 103$ (1.0 equiv)

dichloromethane, $0^{\circ} \mathrm{C}, 5 \mathrm{~h}$<smiles>[R]C1=C(C)C2(C=CC(=O)C=C2)CCN1</smiles>

102b: $\mathrm{R}=\mathrm{Ph}$

104a: $15 \%$

104b: $11 \%$ 
<smiles>[R]C1CCc2ccc(OC)c3cccc(c23)C1[R]</smiles>

105

$$
\begin{gathered}
25 \text { (1.1 equiv), } m \text { CPBA (1.1 equiv) } \\
p \mathrm{TsOH} \cdot \mathrm{H}_{2} \mathrm{O}\left(2.0 \text { equiv), } \mathrm{Bu}_{4} \mathrm{~N}^{+} \mathrm{N}_{3}^{-}\right. \text {(1.1 equiv) } \\
\mathrm{CF}_{3} \mathrm{CH}_{2} \mathrm{OH}, \mathrm{rt}, 8 \mathrm{~h} \\
3 \text { examples }
\end{gathered}
$$$$
n=1,2
$$<smiles>[R]C1=CC=CC2(CC=CC(=O)c3ccccc32)C1</smiles>

106: $60-99 \%$

Scheme 38: lodine(III)-mediated spirocyclization of aryl alkynes 105 to spirocarbocyclic compound 106 by the reaction with bis(iodoarene) 25 in the presence of $m$ CPBA.

Wang and co-workers [110] developed a hypervalent iodinemediated synthesis of ortho-spirocarbocyclic compounds via dearomatization of ortho-substituted phenols. In this reaction, ortho-substituted phenols $\mathbf{1 0 7}$ were cyclized to form spirocarbocyclic compounds $\mathbf{1 0 9}$ in useful yields. All the reactions were performed in a $\mathrm{CF}_{3} \mathrm{CH}_{2} \mathrm{OH} / \mathrm{CH}_{2} \mathrm{Cl}_{2}(1: 1)$ solvent combination using PIDA (15) as an electrophile at $-40{ }^{\circ} \mathrm{C}$ for $10-15$ minutes (Scheme 39). This is an example of an ortho-oxidative phenol dearomatization reaction wherein there is the formation of the steriogenic center at the spiro-ring junction. This approach provides an easy and direct method for the construction of ortho-spirocarbocyclic compounds which is broadly found to originate in most of bioactive natural products $[111,112]$.

\subsection{Application of spirocarbocyclic compounds in natural product synthesis}

In 2003, Kita and co-workers [113,114] employed a iodine(III) reagent during the total synthesis of sulfur-containing alkaloid 112. Initially, the substrates 110 were cyclized to spirodienone derivatives 111 in useful yields using PIFA (31) as source of electrophile in trifluoroethanol at room temperature (Scheme 40). Furthermore, synthesized compounds 111 were converted into the natural product discorhabdin A (112).

In 2006, Honda and co-workers [115] reported the total synthesis of spiro-isoquinoline alkaloid $( \pm)$-annosqualine (1). In this report, the substrate $\mathbf{1 1 3}$ was cyclized to form spirocyclic compound 114 via desilylation with TBAF in THF followed by reaction with $n$-BuLi in hexafluoroisopropanol using PIDA (15) at $4{ }^{\circ} \mathrm{C}$ (Scheme 41). This oxidative cyclization of enamide substrate 113 afforded synthetically useful spiroenamide 114, which was used as key intermediate for total synthesis of annosqualine (1). The synthesis of natural product $\mathbf{1}$ was achieved in two steps starting from synthesized compound 114.

Honda and Shigehisa [116] reported the total synthesis of naturally occuring compound stepharine (3) starting from aro-
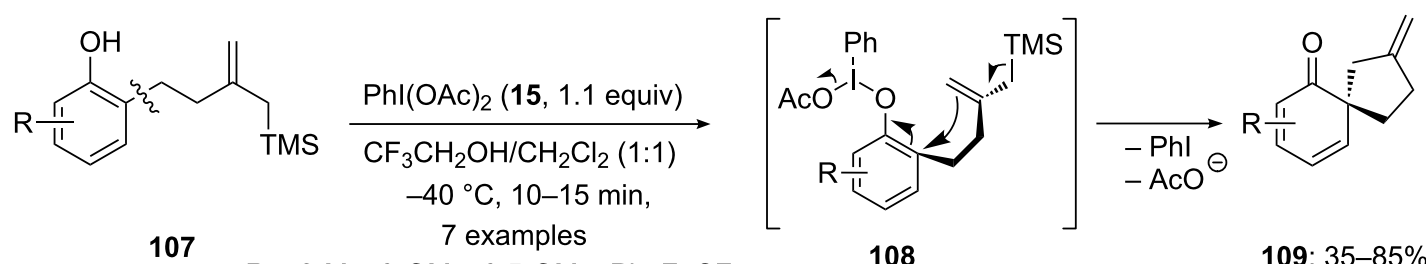

$\mathrm{R}=$ 2-Me, 3-OMe, 3,5-OMe, $\mathrm{Ph}, \mathrm{F}, \mathrm{CF}_{3}$<smiles></smiles>

110

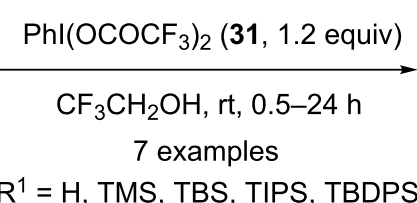

$$
R^{2}=\text { TBS, TIPS, TBDPS }
$$

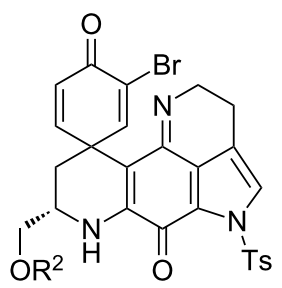

111: $24-49 \%$

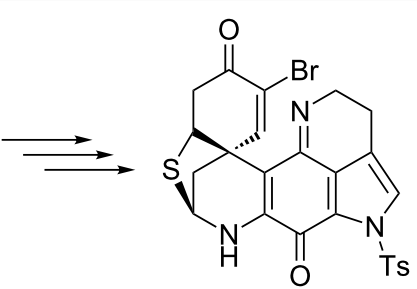

112: discorhabdin A 
<smiles>C=CCOc1cc2c(c(OC)c1OC)CCN(C(=O)c1ccc(OC(C)(C)C)cc1)C2=C</smiles>

113
1. TBAF, THF, rt, $20 \mathrm{~min}$

2. $n$-BuLi, $\mathrm{Phl}(\mathrm{OAc})_{2}$ (15), HFIP, $4{ }^{\circ} \mathrm{C}, 10 \mathrm{~min}$<smiles>C=CCOc1cc2c(c(OC)c1OC)CCN1C(=O)C3(C=CC(=O)C=C3)C=C21</smiles>

114: $73 \%$

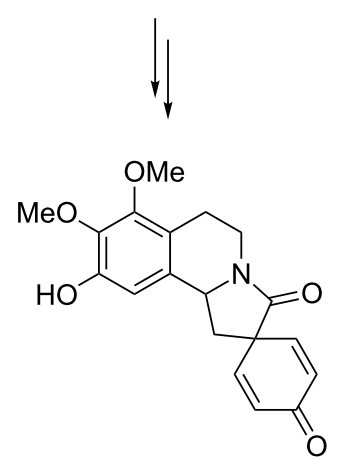

1: ( \pm )-annosqualine

Scheme 41: lodine(III)-mediated cyclization of substrate 113 to spirocyclic compound 114.

matic aldehyde 115. Initially, substituted phenolic compound 116 was prepared in seven steps from aldehyde 115. Furthermore, the synthesized compound $\mathbf{1 1 6}$ was converted into the natural product stepharine (3) by reaction with PIDA (15) in trifluoroethanol (TFE) followed by the reduction with $\mathrm{NaBH}_{4}$. The synthesis of the natural product stepharine (3) was obtained in $90 \%$ yield by starting from phenolic substrate $\mathbf{1 1 6}$ (Scheme 42).

In 2008, Kita and co-workers [117] developed an iodine(III)catalyzed approach for the spirocyclization of $p$-substituted phenols 117 to spirocarbocyclic products 119 in good yields using a catalytic amount of iodoarene $\mathbf{1 1 8}$ and urea $\cdot \mathrm{H}_{2} \mathrm{O}_{2}$ as an oxidant. Probably, the active hypervalent iodine(III) species was generated in situ by the oxidation of iodoaerene $\mathbf{1 1 8}$ in the presence of urea $\cdot \mathrm{H}_{2} \mathrm{O}_{2}$ oxidant (Scheme 43). Furthermore, the synthesized spirocyclic compounds were used as synthetic intermediate for the synthesis of biologically active natural product amaryllidaceae alkaloids such as $( \pm$ )-maritidine (120) [118-120].

In 2009, Kita and co-workers [121] reported the synthesis of various oxygen analogues of naturally occurring compound discorhabdin A starting from substrate $\mathbf{1 1 0}$ in few chemical steps. Discorhabdin A is an alkaloid that shows various biological activities including strong cytotoxic activity [122]. During the first step, starting substrates $\mathbf{1 1 0}$ were cyclized to spirocyclic compounds 111 in useful yields using PIFA (31) in presence of montmorillonite K10 in trifluoroethanol (Scheme 44). Furthermore, synthesized spirocyclic compounds $\mathbf{1 1 1}$ were used as key precursors for the synthesis of oxygen analogues of discorhabdin A (121).<smiles>COc1cc(C=O)cc(Br)c1OC</smiles>

115
1. PIDA (15, 1.1 equiv)

$\mathrm{CF}_{3} \mathrm{CHOH}, 0^{\circ} \mathrm{C}, 5 \mathrm{~min}$

2. $\mathrm{NaBH}_{4}, 3 \mathrm{~h}$

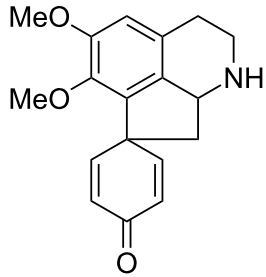

3: stepharine: $90 \%$ 
<smiles>[R][Z17](Cc1ccc(O)cc1)N([X])Cc1cc([R])c([R])c([R])c1</smiles>

117

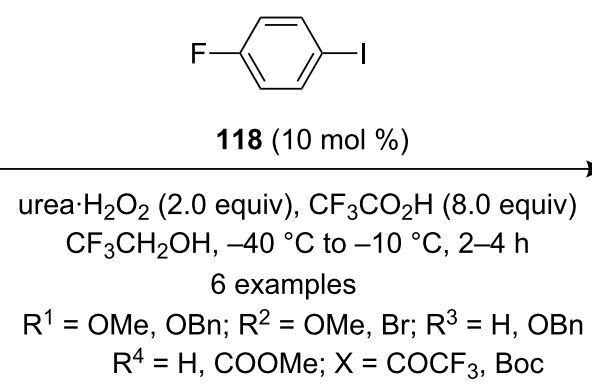<smiles>[R]c1cc2c(c([R])c1[R])C1(C=CC(=O)C=C1)CC([R])N([X])C2</smiles>

119: $55-80 \%$<smiles>CC#CCOc1cc2c(cc1OC)CN1CCCC23CCC(=O)CC13C</smiles>

120: ( \pm )-maritidine

Scheme 43: lodine(III)-catalyzed spirocyclization of phenols 117 to spirocarbocyclic products 119 using iodoarene 118 in the presence of the oxidant urea $\cdot \mathrm{H}_{2} \mathrm{O}_{2}$

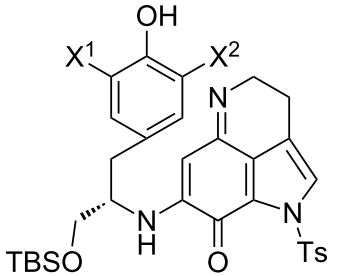

110

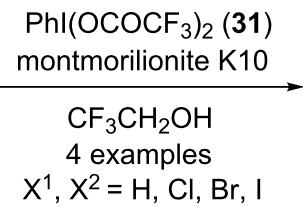

$\mathrm{X}^{1}, \mathrm{X}^{2}=\mathrm{H}, \mathrm{Cl}, \mathrm{Br}$,

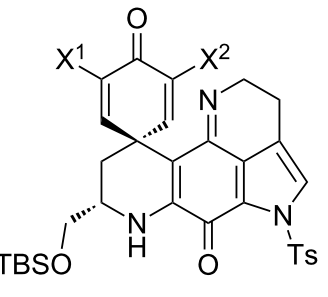

111: $37-57 \%$
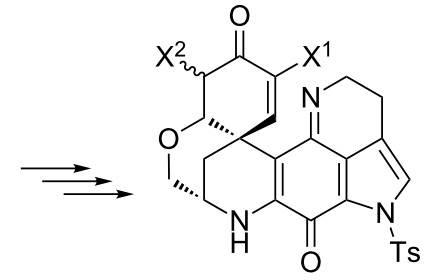

121

Scheme 44: PIFA-mediated spirocyclization of 110 to spirocyclic compound 111 using PIFA (31) as electrophile.

\section{Synthesis of miscellaneous spirocyclic} compounds

\subsection{Using stoichiometric amounts of iodine(III)} reagents

In 2002, Ciufolini and co-workers [123] reported the spirocyclization of various phenolic sulfonamides 122 to spiropyrrolidines 123 using PIDA (15). In this reaction, sulfonamides 122 undergo $\mathrm{N}$-acylation, wherein various homotyramine sulfon- amides were treated with electrophile PIDA (15) in hexafluoroisopropanol to give the spirocyclic products $\mathbf{1 2 3}$ in high yields (Scheme 45). However, the similar spirocyclization could not successfully applied for the construction of six-membered spiropiperidine systems.

In 2015, Jain and Ciufolini [124] developed PIDA-mediated spirocyclization of 2-naphtholic sulfonamides 124 to spiro-
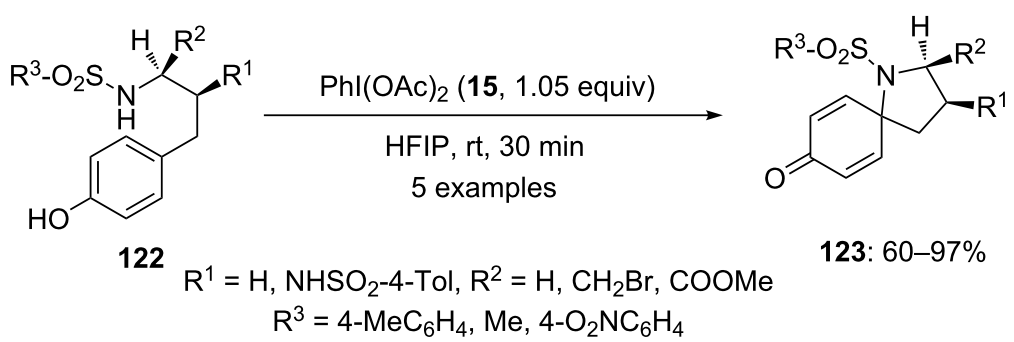

123: $60-97 \%$

Scheme 45: PIDA-mediated spirocyclization of phenolic sulfonamide 122 to spiroketones 123. 
pyrrolidine derivatives $\mathbf{1 2 5}$. The spirocyclization reactions were carried out by treating $N$-sulfonamide substrates 124 with (diacetoxyiodo)benzene (15) in trifluoroacetic acid (TFA) and spiropyrrolidines $\mathbf{1 2 5}$ were isolated in good to excellent yields (Scheme 46). However, the presence of an electron-donating functionality at para-position to the phenolic group induced no spirocyclization product.

In 2016, Bray and Shirley [125] reported the oxidative spirocyclization of meta-substituted phenol $\mathbf{1 2 6}$ to tricyclic spiroketals $\mathbf{1 2 7} \mathbf{a}, \mathbf{b}$ in $56 \%$ yield using PIDA (15) as electrophilic species in acetonitrile at room temperature (Scheme 47). The mixture of both isomers was separated by flash column chromatography and the stereochemistry of major isomer 127 a was assigned on the basis of NOE. This spirocyclic functionality is the basic nucleus found in the phorbaketal family of natural products.

\subsection{Stereoselective synthesis of chiral spirocyclic ketals}

Recently, Ishihara and co-workers [126] synthesized chiral $C_{2}$-symmetric iodoarene 129a and 129b (Figure 3) in few steps and used as precatalyst in iodine(III)-catalyzed enantioselective synthesis of spiroketals with high selectivities.

In this report, substrates $\mathbf{1 2 8}$ were reacted with $10 \mathrm{~mol} \%$ of chiral iodoarene 129a and 129b in the presence of $m \mathrm{CPBA}$ oxidant in chloroform at $0{ }^{\circ} \mathrm{C}$. The desired ortho-spirocyclic ketals 130 were obtained in high yields with more than 93\% enantiomeric excess (Scheme 48). Interestingly, the higher selectivities were observed with chiral hypervalent iodine(III) reagent 129 b compared to $129 a$.

\subsection{Application of miscellaneous spirocyclic compounds in natural product synthesis}

Various hypervalent iodine reagents have been proved as vital reagents during the synthesis of several natural products containing spirocyclic skeleton. In 1999, Ley and co-workers [127] used polymeric PIDA reagent $\mathbf{1 3 2}$ to achieve the synthesis of spirocyclic core of natural product $(+)$-epidihydromaritidine (134). In this report, para-substituted phenol 131 was cyclized to spirodienone 133 using polymer supported (diacetoxy)iodobenzene reagent 132 (Scheme 49). The desired product 133 was<smiles>[R]c1cc(CCCNS(=O)(=O)O)c(O)c2ccccc12</smiles>

124

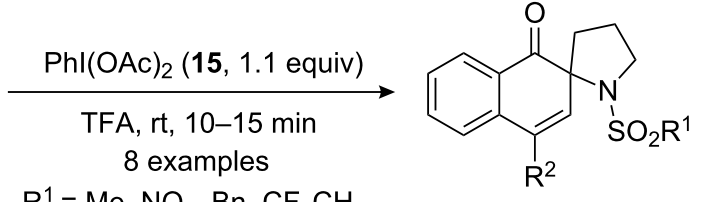

125: $45-96 \%$

Scheme 46: lodine(III)-mediated oxidative spirocyclization of 2-naphthol derivatives 124 to spiropyrrolidines 125

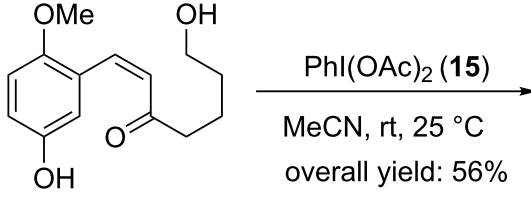

126

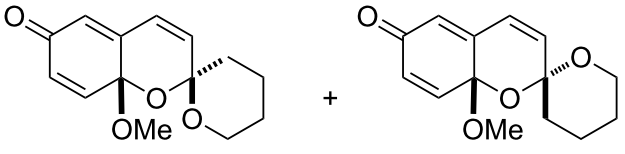

$127 a$
$127 b$<smiles>CC(=O)NCC(C)Oc1cccc(OC(C)CNC(C)=O)c1I</smiles>

$129 a$<smiles>Cc1cc(C(F)(F)F)cc(C)c1C(=O)NC[C@H](C)Oc1cccc(OC(C)CNC(=O)c2c([N+](=O)[O-])cc(C(F)(F)F)cc2[N+](=O)[O-])c1I</smiles>

$129 b$ 
<smiles>[R]c1ccc2c(O)c(OC([Y7])([Y7])CO)c([R])c([R])c2c1</smiles>

128

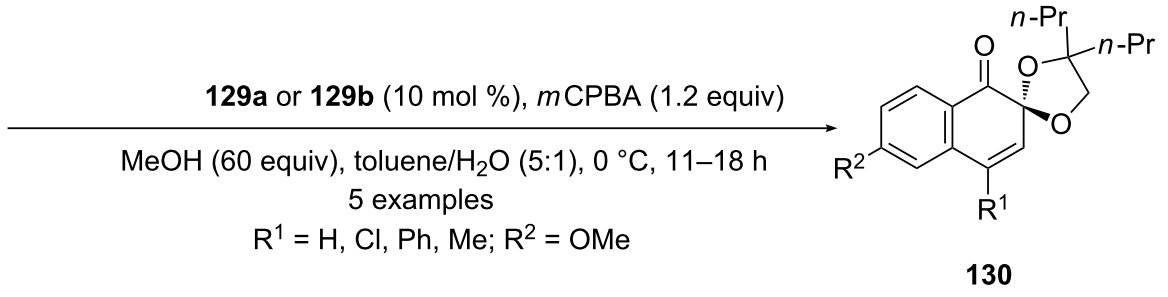

(yield: $53-81 \%$; ee $>93 \%$ )

Scheme 48: lodine(III)-catalyzed oxidative spirocyclization of substituted phenols 128 to spirocyclic ketals 130.<smiles>COc1ccc(CN(CCc2ccc(O)cc2)C(=O)C(F)(F)F)cc1OC</smiles>

131

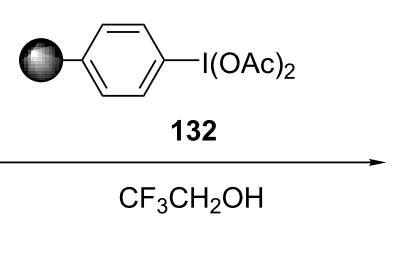

132

$\mathrm{CF}_{3} \mathrm{CH}_{2} \mathrm{OH}$<smiles></smiles>

133: $70 \%$<smiles>COc1cc2c(cc1OC)C1(CC2)CCC(O)CC1</smiles>

134: (+)-epidihydromaritidine

Scheme 49: Oxidative spirocyclization of para-substituted phenol 131 to spirodienone 133 using polymer supported iodine(III) reagent 132.

obtained in $70 \%$ yield without conventional work-up procedure and purification by chromatographic technique. Furthermore, synthesized spirocyclic compound $\mathbf{1 3 3}$ was converted into the alkaloid (+)-epidihydromaritidine (134) in three chemical steps.

Furthermore, Wipf and co-workers [128] reported a new synthetic route for the synthesis of deoxypreussomerin A (137) and palmarumycin $\mathrm{CP}_{1}$ (138). During the first step, the synthesis of spirocyclic compound $\mathbf{1 3 6}$ was achieved in $87 \%$ yield by the reaction of PIDA (15) with the naphthol derivative 135 in trifluoroethanol at room temperature. Additionally, synthesized compound $\mathbf{1 3 6}$ was used as key intermediate in the total synthesis of natural products $\mathbf{1 3 7}$ and $\mathbf{1 3 8}$ (Scheme 50). Additionally, more analogues of palmarumycin $\mathrm{CP}_{1}$ were synthesized later<smiles>Oc1ccc(Oc2cccc3cccc(O)c23)c2c1C(O)CCC2</smiles>

135

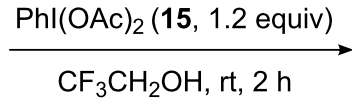<smiles>O=C1C=CC2(Oc3cccc4cccc(c34)O2)C2=C1C(O)CCC2</smiles>

136: $87 \%$<smiles>C[I+]I=CI</smiles><smiles>C=C=CC=C</smiles>

137: deoxypreussomerin A

138: palmarumycin $\mathrm{CP}_{1}$ 
which were showing good thioredoxin-thioredoxin reductase (Trx-1/TrxR) inhibitory activity [129]. It was observed that the introduction of enone functionality in naphthoquinone spiroketal enhances the biological activity of palmarumycin $\mathbf{1 3 8}$.

Furthermore, Ley and co-workers [130] employed polymersupported iodine(III) reagent during the total synthesis of Amaryllidaceae alkaloid (+)-plicamine (141). In this report, spirodienone 140 was synthesized in $82 \%$ yield by the oxidative spirocyclization of $p$-substituted phenolic substrate 139 using polymer-supported iodonium diacetate 132 in 2,2,2-trifluoroethanol/DCM at $-10{ }^{\circ} \mathrm{C}$ (Scheme 51). Additionally, the synthesized functionalized spirodienone $\mathbf{1 4 0}$ was used as precursor for the synthesis of (+)-plicamine (141).
In 2002, Quideau and co-workers [131] developed the synthesis of marine sesquiterpenoid (+)-puupehenone starting from catechol derivative 142. Marine sesquiterpenoids are mainly known for their biological importance such as antitumor, antiviral and antibiotic properties [132]. In this report, the catechol-derived starting substrate 142 was cyclized to spirocyclic product 143 in 67\% yield using PIFA (31) as suitable electrophile in dichloromethane at $-25{ }^{\circ} \mathrm{C}$ (Scheme 52). Furthermore, the spirocyclic product $\mathbf{1 4 3}$ assists as the key synthetic intermediate in the synthesis of the marine natural product (+)-puupehenone (144).

In 2005, Marco and co-workers [133] reported the synthesis of naturally occurring spiroacetals aculeatin A (146a) and<smiles>NC(=O)C(c1ccc(O)cc1)N(Cc1ccc2c(c1)OCO2)C(=O)C(F)(F)F</smiles>

139

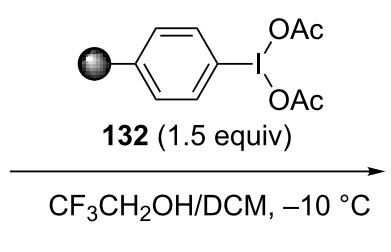<smiles>CNC(=O)C(C1C=CC(=O)C=C1)N1Cc2cc3c(cc2C1)OCO3</smiles>

140: $82 \%$

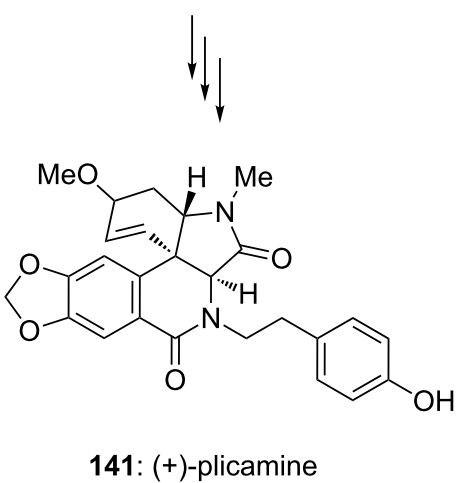

Scheme 51: Oxidative spirocyclization of phenolic compound 139 to spirodienone 140 using polymer-supported PIDA 132.<smiles>C[C@H]1CCC[C@]2(C)[C@@H]1[C@@H](C)CC[C@H]2C</smiles>

142<smiles>CC[C@@]1(C)OC2(C=CC(=O)C=C2)CC1[C@]1(C)CCCC[C@@H]1C</smiles>

143: $67 \%$<smiles>CC1(C)CCC[C@@]2(C)OC3=CC(=O)C(O)=CC3=C[C@@H]12</smiles>

144: (+)-puupehenone 
aculeatin B (146b) and iodine(III) reagent was used as an electrophile in one step during their synthesis. In this report, $p$-substituted phenolic substrate $\mathbf{1 4 5}$ was directly cyclized to naturally occuring spirocyclic optical isomers 146a and $146 \mathrm{~b}$ using PIFA (31) in solvent combination of $\mathrm{CH}_{3} \mathrm{COCH}_{3} / \mathrm{H}_{2} \mathrm{O}$ $(9: 1)$ at room temperature for $24 \mathrm{~h}$. The spirocyclic compound 146 was obtained as two optical isomers in 5.5:1 ratio with overall $65 \%$ yield (Scheme 53 ).

Furthermore, Peuchmaur and Wong [134] developed a new synthetic route for the total synthesis of the natural product $( \pm$ )-aculeatin starting from substrate 147. $( \pm)$-Aculeatin and its derivatives possessing spirocyclic skeleton are known for their antibacterial and antiprotozoal properties [135]. In this report, substrate $\mathbf{1 4 7}$ was cyclized to spiroketals, i.e., (-)-aculeatin (146a) and (+)-146b in 3:2 ratio. Herein, 1.0 equivalent of PIFA (31) was used as an electrophile, 0.4 equivalents of TFA as nonnucleophilic counter anion in solvent combination of $\mathrm{Me}_{2} \mathrm{CO} /$ $\mathrm{H}_{2} \mathrm{O}(10: 1)$ at room temperature for 15 minutes (Scheme 54). The reaction proceeds through phenolic oxidative cyclization of phenolic substrate $\mathbf{1 4 7}$ which is the key step in the overall synthesis. The absolute configuration of the synthesised compound was determined by comparing the optical rotary values with that of natural compound (-)-aculeatin (146a) and (+)-aculeatin (146b).

In the continuation to previous work, the same research group [136] reported the synthesis of aculeatin D. In this report, the $p$-substituted phenolic compound $\mathbf{1 4 8}$ was directly cyclized to natural product aculeatin D (149) in 77\% yield using PIFA (31) (Scheme 55).

In 2006, Ley and co-workers [137] reported the total synthesis of natural product $( \pm)$-oxomaritidine (151) starting from phenolic substrates and polymer-supported hypervalent iodine reagent was used in one step. In this report, $p$-substituted phenolic compound $\mathbf{1 3 1}$ was cyclized to spirocyclic compound 133 in $50 \%$ yield containing a seven membered ring system. The cyclization reaction was carried out using polymer-supported PIFA reagent $\mathbf{1 5 0}$ as an electrophile and trifluoroacetic anhydride (TFAA) as an additive at $80{ }^{\circ} \mathrm{C}$ in a microreactor without using any solvent (Scheme 56). Additionally, synthesised compound $\mathbf{1 3 3}$ was used as precursor for the synthesis of ( \pm )-oxomaritidine (151).

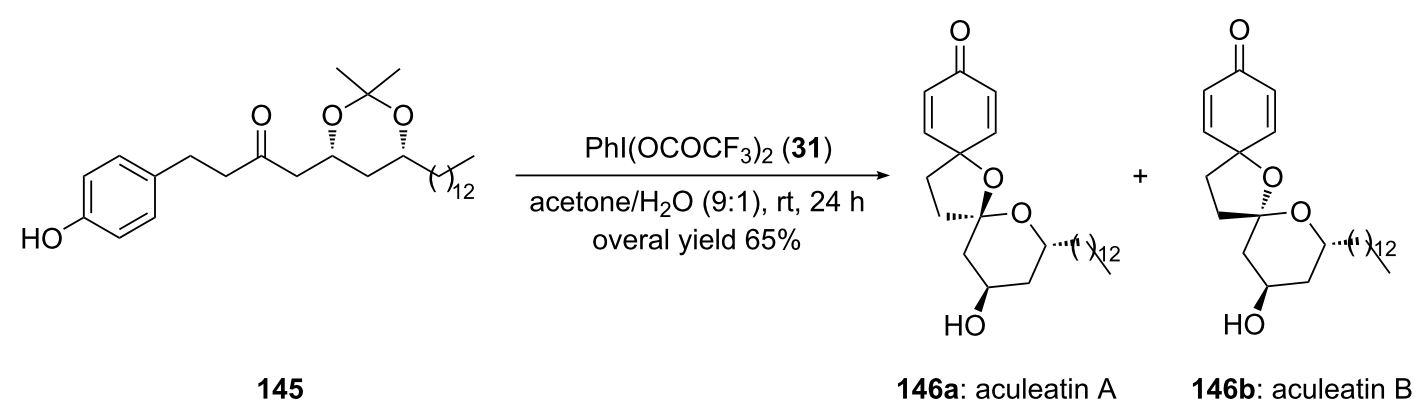

Scheme 53: Oxidative spirocyclization of $p$-substituted phenolic substrate 145 to aculeatin A (146a) and aculeatin B (146b) using PIFA (31).<smiles>[X]C(C[C@@H](O)CC(=O)O)OCc1ccc(OC)cc1</smiles>

147

\section{$\operatorname{Phl}\left(\mathrm{OCOCF}_{3}\right)_{2}(\mathbf{3 1}, 1.2$ equiv) TFA ( 0.4 equiv)}

acetone/ $\mathrm{H}_{2} \mathrm{O}(10: 1), \mathrm{rt}, 15 \mathrm{~min}$

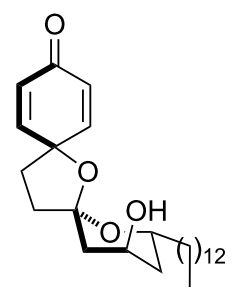

146a: $48 \%$ $(-)$-aculeatin A<smiles>O=C1C=CC2(C=C1)CCC(O)C(O)C2</smiles>

146b: $34 \%$

(+)-aculeatin B 
<smiles>[Y20]C([18OH])CC([18OH])CC(=O)CCc1ccc(O)cc1</smiles>

148
1. TASF, DMF, $0^{\circ} \mathrm{C}, 1.5 \mathrm{~h}$ then $\mathrm{rt}, 4 \mathrm{~h}$

2. $\mathrm{Phl}\left(\mathrm{OCOCF}_{3}\right)_{2}(31)$ acetone/ $\mathrm{H}_{2} \mathrm{O}(9: 1)$, rt, $30 \mathrm{~min}$

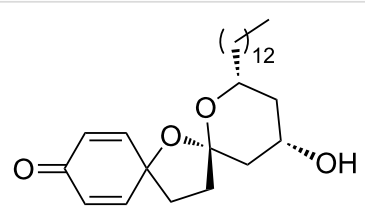

149: aculeatin D: $77 \%$

Scheme 55: Oxidative spirocyclization of $p$-substituted phenolic substrate 148 to aculeatin D (149) using electrophilic species PIFA (31).<smiles>COc1ccc(CN(CCc2ccc(O)cc2)C(=O)C(F)(F)F)cc1OC</smiles>

131<smiles>COc1cc2c(cc1OC)C1(CCC(=O)CC1)CN(C(=O)C(F)(F)F)CCC21C=CC(=O)C=C1</smiles>

133: $50 \%$

151: ( \pm )-oxomaritidine

Scheme 56: Cyclization of phenolic substrate 131 to spirocyclic product 133 using polymer-supported PIFA 150.

In 2007, Lalic and Corey [138] reported the synthetic pathway for the synthesis of the naturally occurring antibiotic platensimycin (154) which is isolated from Streptomyces platensis. In this report, 6-methoxy-1,4-naphthoquinone-4-ethylene ketal (153) was synthesized by intermolecular oxidative cyclization of 7-methoxy- $\alpha$-naphthol (152) with ethylene glycol in the presence of PIFA (31) in acetonitrile. The reaction product 153 was isolated in $80 \%$ yield (Scheme 57). Additionally, the synthesised compound 153 was converted into the antibiotic platensimycin (154) after nine chemical steps.

Furthermore, the same electrophilic species $\mathbf{1 5}$ was used to cyclize ortho-substituted phenolic compounds $\mathbf{1 5 5}$ to spiroketals 156 by Quideau and co-workers [139]. The cyclization reactions were performed in trifluoroethanol and spirocyclic ketals 156 were isolated in useful yields (Scheme 58). Additionally, the synthesized spiroketal $156\left(\mathrm{R}=\mathrm{iPr} ; \mathrm{R}^{1}=\mathrm{iPr}\right)$ was used as substrate for the synthesis of natural product $(+)$-biscarvacrol (157).
Koag and Lee [140] reported the synthesis of a spiroketal by radical cyclization of a steroidal alkylamine in presence of PIDA (15) as oxidant and molecular iodine in dichloromethane at low temperature. It is an example of hypoiodite-mediated radical cyclization wherein the oxazaspiroketal moiety is formed which is further used as key intermediate for the synthesis of the natural product cephalostatin.

Additionally, spiroketals 159 were also synthesised by enatioselective spirocyclization of ortho-substituted phenols $\mathbf{1 5 8}$ using similar chiral auxiliaries 129a or 129b under similar reaction conditions mentioned in Scheme 48. Furthermore, the synthesized spiroketal $159\left(\mathrm{R}^{2}=\mathrm{iPr} ; \mathrm{R}^{4}=\mathrm{SiMe}_{3}\right)$ was used as synthetic intermediate for enantioselective synthesis of natural product (-)-biscarvacrol [8] (Scheme 59). Additionally, Parra and Reboredo compiled a review article where authors have covered various aspects of stereoselective spirocyclizations using chiral hypervalent iodine reagents [44]. This review article would be more interesting for readers and provides some significant<smiles>COc1ccc2cccc(O)c2c1</smiles>

152<smiles>COc1ccc2c(c1)C(=O)C=CC21OCCO1</smiles>

153: $80 \%$

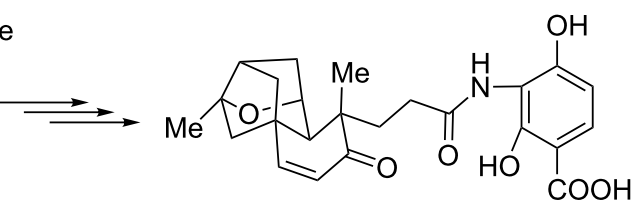

154: platensimycin

Scheme 57: lodine(III)-mediated oxidative intermolecular spirocyclization of 7-methoxy-a-naphthol (152) to spirocyclic compound 153 


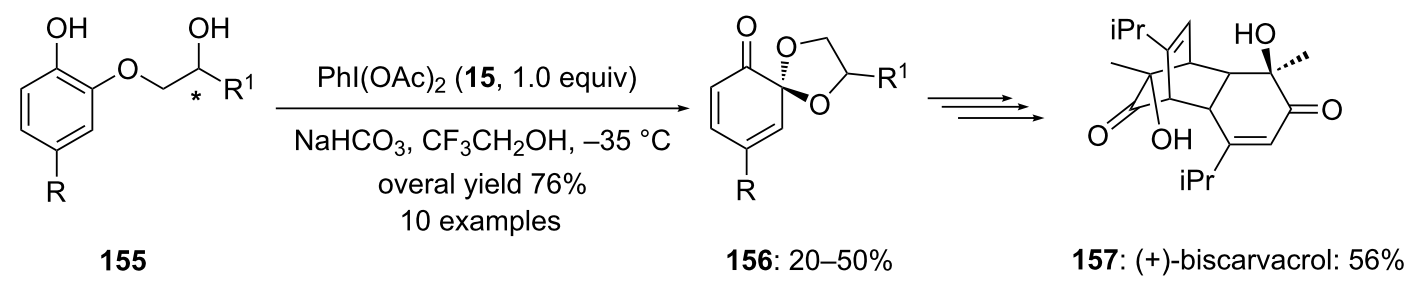

$\mathrm{R}=t-\mathrm{Bu}, \mathrm{iPr}, \mathrm{OMe}, \mathrm{Br}, \mathrm{I} ; \mathrm{R}^{1}=t-\mathrm{Bu}, \mathrm{Et}, n-\mathrm{Dec}$

Scheme 58: Oxidative cyclization of phenols 155 to spiro-ketals 156 using electrophilic species PIDA (15).

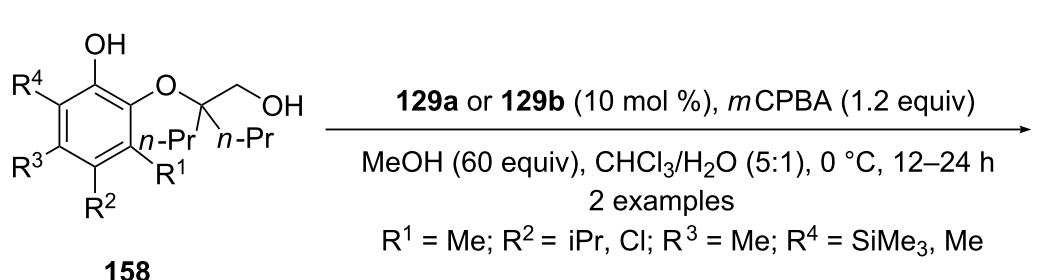

158

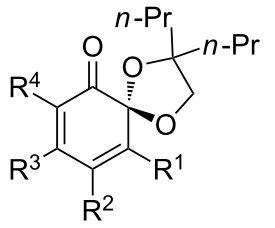

159: $54-80 \%$; ee $<90 \%$

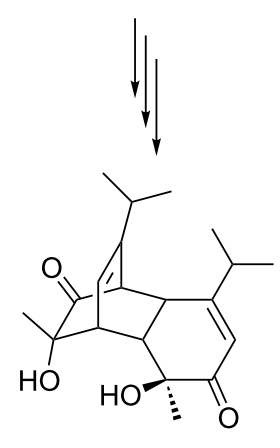

160: (-)-biscarvacrol

Scheme 59: lodine(III)-catalyzed oxidative spirocyclization of ortho-substituted phenols 158 to spirocyclic ketals 159.

information about the utility of chiral iodine(III) reagents in enantioselective spirocyclizations with suitable detail.

\section{Conclusion}

In this review article, we have summarized different approaches for the synthesis of spirocyclic scaffolds using hypervalent iodine reagents in stoichiometric or catalytic amounts. Various iodine(III) reagents such as (diacetoxyiodo)benzene, [bis(trifluoroacetoxy)iodo]benzene and Koser's reagent have been used to achieve a variety of spirocyclization reactions under mild reaction conditions. Various hypervalent iodine-catalyzed spirocyclization of functionalized phenols and aromatic amines have been successfully developed using iodoarenes as precatalyst in the presence of terminal oxidants. In addition, this review highlights various stereoselective spirocyclizations using chiral hypervalent iodine reagents. Finally, the recent applications of hypervalent iodine reagents in natural product synthesis are also covered.

\section{Acknowledgements}

Fateh V Singh is thankful to the DST New Delhi for providing Start-Up Research Grant (SB/FT/CS-068/2014) as financial support. All the authors are thankful to the chemistry division, VIT University, Chennai Campus, Chennai.

\section{References}

1. Nemoto, T.; Hamada, Y. Yuki Gosei Kagaku Kyokaishi 2015, 73, 977-986. doi:10.5059/yukigoseikyokaishi.73.977

2. Li, Y.; Cheng, L.; Liu, X.; Li, B.; Sun, N. Beilstein J. Org. Chem. 2014, 10, 2886-2891. doi:10.3762/bjoc.10.305

3. Zuo, Z.; Yang, X.; Liu, J.; Nan, J.; Bai, L.; Wang, Y.; Luan, X. J. Org. Chem. 2015, 80, 3349-3356. doi:10.1021/acs.joc.5b00316

4. Sun, W.; Li, G.; Hong, L.; Wang, R. Org. Biomol. Chem. 2016, 14, 2164-2176. doi:10.1039/C5OB02526E

5. Petersen, A. B.; Rønnest, M. H.; Larsen, T. O.; Clausen, M. H. Chem. Rev. 2014, 114, 12088-12107. doi:10.1021/cr400368e

6. Bhakuni, D. S.; Gupta, S. J. Nat. Prod. 1982, 45, 407-411. doi:10.1021/np50022a007 
7. Pouységu, L.; Deffieux, D.; Quideau, S. Tetrahedron 2010, 66, 2235-2261. doi:10.1016/j.tet.2009.12.046

8. Pouységu, L.; Chassaing, S.; Dejugnac, D.; Lamidey, A.-M.; Miqueu, K.; Sotiropoulos, J.-M.; Quideau, S. Angew. Chem., Int. Ed. 2008, 47, 3552-3555. doi:10.1002/anie.200705816

9. Zheng, Y.; Tice, C. M.; Singh, S. B. Bioorg. Med. Chem. Lett. 2014, 24, 3673-3682. doi:10.1016/j.bmcl.2014.06.081

10. Zheng, Y.-J.; Tice, C. M. Expert Opin. Drug Discovery 2016, 11, 831-834. doi:10.1080/17460441.2016.1195367

11. Yang, Y.-L.; Chang, F.-R.; Wu, Y.-C. Helv. Chim. Acta 2004, 87, 1392-1399. doi:10.1002/hlca.200490127

12. Oxford, A. E.; Raistrick, H.; Simonart, P. Biochem. J. 1939, 33, 240-248. doi:10.1042/bj0330240

13. Davenport-Hines, R. P. T.; Slinn, J. Glaxo: A History to 1962; Cambridge University Press: Cambridge, 1992; p 219.

14. Cava, M. P.; Nomura, K.; Schlessinger, R. H.; Buck, K. T.; Douglas, B.; Raffauf, R. F.; Weisbach, J. A. Chem. Ind. 1964, 282-283.

15. Ohtake, Y.; Sato, T.; Kobayashi, T.; Nishimoto, M.; Taka, N.; Takano, K.; Yamamoto, K.; Ohmori, M.; Yamaguchi, M.; Takami, K.; Yeu, S.-Y.; Ahn, K.-H.; Matsuoka, H.; Morikawa, K.; Suzuki, M.; Hagita, H.; Ozawa, K.; Yamaguchi, K.; Kato, M.; Ikeda, S. J. Med. Chem. 2012, 55, 7828-7840. doi:10.1021/jm300884k

16. Olver, I. Lancet Oncol. 2015, 16, 1006-1007. doi:10.1016/S1470-2045(15)00096-0

17. Basarab, G. S.; Doig, P.; Galullo, V.; Kern, G.; Kimzey, A.; Kutschke, A.; Newman, J. P.; Morningstar, M.; Mueller, J.; Otterson, L.; Vishwanathan, K.; Zhou, F.; Gowravaram, M. J. Med. Chem. 2015, 58, 6264-6282. doi:10.1021/acs.jmedchem.5b00863

18. Wirth, T. Angew. Chem. 2001, 113, 2893-2895. doi:10.1002/1521-3757(20010803)113:15<2893::aid-ange2893>3.0.c o;2-f

Angew. Chem. Int. Ed. 2001, 40, 2812-2814 doi:10.1002/1521-3773(20010803)40:15<2812::AID-ANIE2812>3.0.C $0 ; 2-X$

19. Wirth, T. In Organic Synthesis Highlights; Schmalz, H.-G.; Wirth, T., Eds.; Wiley-VCH: Weinheim, 2003; p 144.

20. Wirth, T. Hypervalent lodine Chemistry. In Topics in Current Chemistry; Wirth, T., Ed.; Springer-Verlag: Berlin Heidelberg, 2003; Vol. 224. doi:10.1007/3-540-46114-0

21. Zhdankin, V. V.; Stang, P. J. Chem. Rev. 2002, 102, 2523-2584. doi:10.1021/cr010003+

22. Wirth, T. Angew. Chem. 2005, 117, 3722-3731. doi:10.1002/ange.200500115 Angew. Chem. Int. Ed. 2005, 44, 3656-3665. doi:10.1002/anie.200500115

23. Zhdankin, V. V.; Stang, P. J. Chem. Rev. 2008, 108, 5299-5358. doi:10.1021/cr800332c

24. Zhdankin, V. V. ARKIVOC 2009, No. 1, 1-62. doi:10.3998/ark.5550190.0010.101

25. Farooq, U.; Shah, A.-U.-H. A.; Wirth, T. Angew. Chem. 2009, 121, 1036-1038. doi:10.1002/ange.200805027 Angew. Chem. Int. Ed. 2009, 48, 1018-1020. doi:10.1002/anie.200805027

26. Zhdankin, V. V. J. Org. Chem. 2011, 76, 1185-1197. doi:10.1021/jo1024738
27. Singh, F. V.; Wirth, T. Oxidative Functionalization with Hypervalent Halides. In Comprehensive Organic Synthesis II, 2nd ed.; Molander, G. A.; Knochel, P., Eds.; Elsevier: Oxford, 2014; Vol. 7, pp 880-933. doi:10.1016/B978-0-08-097742-3.00735-7

28. Moriarty, R. M. J. Org. Chem. 2005, 70, 2893-2903. doi:10.1021/jo050117b

29. Ladziata, U.; Zhdankin, V. V. Synlett 2007, 527-537. doi:10.1055/s-2007-967983

30. Merritt, E. A.; Olofsson, B. Angew. Chem. 2009, 121, 9214-9234. doi:10.1002/ange.200904689 Angew. Chem. Int. Ed. 2009, 48, 9052-9070. doi:10.1002/anie.200904689

31. Yoshimura, A.; Zhdankin, V. V. Chem. Rev. 2016, 116, 3328-3435. doi:10.1021/acs.chemrev.5b00547

32. Quideau, S.; Pouységu, L.; Deffieux, D. Synlett 2008, 467-495. doi:10.1055/s-2008-1032094

33. Uyanik, M.; Ishihara, K. Chem. Commun. 2009, 2086-2099. doi:10.1039/B823399C

34. Liang, H.; Ciufolini, M. A. Tetrahedron 2010, 66, 5884-5892. doi:10.1016/j.tet.2010.05.020

35. Satam, V.; Harad, A.; Rajule, R.; Pati, H. Tetrahedron 2010, 66, 7659-7706. doi:10.1016/j.tet.2010.07.014

36. Guérard, K. C.; Sabot, C.; Beaulieu, M.-A.; Giroux, M.-A.; Canesi, S. Tetrahedron 2010, 66, 5893-5901. doi:10.1016/j.tet.2010.03.096

37. Singh, F. V.; Wirth, T. Org. Lett. 2011, 13, 6504-6507. doi:10.1021/ol202800k

38. Mangaonkar, S. R.; Kole, P. B.; Singh, F. V. Synlett 2018, 199-202. doi:10.1055/s-0036-1588575

39. Merritt, E. A.; Olofsson, B. Synthesis 2011, 517-538. doi:10.1055/s-0030-1258328

40. Tinnis, F.; Stridfeldt, E.; Lundberg, H.; Adolfsson, H.; Olofsson, B. Org. Lett. 2015, 17, 2688-2691. doi:10.1021/acs.orglett.5b01079

41. Ghosh, R.; Stridfeldt, E.; Olofsson, B. Chem. - Eur. J. 2014, 20 , 8888-8892. doi:10.1002/chem.201403523

42. Ghosh, R.; Lindstedt, E.; Jalalian, N.; Olofsson, B. ChemistryOpen 2014, 3, 54-57. doi:10.1002/open.201402006

43. Brown, M.; Delorme, M.; Malmedy, F.; Malmgren, J.; Olofsson, B.; Wirth, T. Synlett 2015, 26, 1573-1577. doi:10.1055/s-0034-1380687

44. Parra, A.; Reboredo, S. Chem. - Eur. J. 2013, 19, 17244-17260. doi:10.1002/chem.201302220

45. Wang, H.; Fan, R. J. Org. Chem. 2010, 75, 6994-6997. doi:10.1021/jo1014245

46. Moriarty, R. M.; Tyagi, S.; Kinch, M. Tetrahedron 2010, 66, 5801-5810. doi:10.1016/j.tet.2010.05.005

47. Bose, D. S.; Idrees, M. Synthesis 2010, 393-402. doi:10.1055/s-0029-1217136

48. Pardo, L. M.; Tellitu, I.; Domínguez, E. Synthesis 2010, 971-978. doi:10.1055/s-0029-1219218

49. Du, X.; Chen, H.; Chen, Y.; Chen, J.; Liu, Y. Synlett 2011, 1010-1014. doi:10.1055/s-0030-1259717

50. Wardrop, D. J.; Yermolina, M. V.; Bowen, E. G. Synthesis 2012, 44, 1199-1207. doi:10.1055/s-0031-1290750

51. Singh, F. V.; Wirth, T. Synthesis 2012, 44, 1171-1177. doi:10.1055/s-0031-1290588

52. Paz, N. R.; Santana, A. G.; Francisco, C. G.; Suárez, E.; González, C. C. Org. Lett. 2012, 14, 3388-3391. doi:10.1021/ol3013638

53. Kajiyama, D.; Saitoh, T.; Yamaguchi, S.; Nishiyama, S. Synthesis 2012, 44, 1667-1671. doi:10.1055/s-0031-1291006 
54. Hempel, C.; Weckenmann, N. M.; Maichle-Moessmer, C.; Nachtsheim, B. J. Org. Biomol. Chem. 2012, 10, 9325-9329. doi:10.1039/C2OB26815A

55. Mizar, P.; Wirth, T. Angew. Chem. 2014, 126, 6103-6107. doi:10.1002/ange.201400405

Angew. Chem. Int. Ed. 2014, 53, 5993-5997. doi:10.1002/anie.201400405

56. Qian, G.; Liu, B.; Tan, Q.; Zhang, S.; Xu, B. Eur. J. Org. Chem. 2014, 4837-4843. doi:10.1002/ejoc.201402456

57. Mizar, P.; Burrelli, A.; Günther, E.; Söftje, M.; Farooq, U.; Wirth, T. Chem. - Eur. J. 2014, 20, 13113-13116. doi:10.1002/chem.201404762

58. Yoshimura, A.; Koski, S. R.; Fuchs, J. M.; Saito, A.; Nemykin, V. N.; Zhdankin, V. V. Chem. - Eur. J. 2015, 21, 5328-5331. doi:10.1002/chem.201500335

59. Mizar, P.; Niebuhr, R.; Hutchings, M.; Farooq, U.; Wirth, T. Chem. - Eur. J. 2016, 22, 1614-1617. doi:10.1002/chem.201504636

60. Singh, F. V.; Wirth, T. Synthesis 2013, 45, 2499-2511. doi:10.1055/s-0033-1339679

61. Brown, M.; Kumar, R.; Rehbein, J.; Wirth, T. Chem. - Eur. J. 2016, 22, 4030-4035. doi:10.1002/chem.201504844

62. Malmedy, F.; Wirth, T. Chem. - Eur. J. 2016, 22, 16072-16077. doi:10.1002/chem.201603022

63. Maertens, G.; L'Homme, C.; Canesi, S. Front. Chem. (Lausanne, Switz.) 2015, 2, No. 115. doi:10.3389/fchem.2014.00115

64. Yeung, C. S.; Dong, V. M. Chem. Rev. 2011, 111, 1215-1292. doi:10.1021/cr100280d

65. Tamura, Y.; Yakura, T.; Haruta, J.; Kita, Y. J. Org. Chem. 1987, 52, 3927-3930. doi:10.1021/jo00226a041

66. Rama Krishna, K. V.; Sujatha, K.; Kapil, R. S. Tetrahedron Lett. 1990, 31, 1351-1352. doi:10.1016/S0040-4039(00)88804-8

67. Kita, Y.; Tohma, H.; Kikuchi, K.; Inagaki, M.; Yakura, T. J. Org. Chem. 1991, 56, 435-438. doi:10.1021/jo00001a082

68. Wipf, P.; Kim, Y. J. Org. Chem. 1993, 58, 1649-1650. doi:10.1021/jo00059a004

69. Ficht, S.; Mülbaier, M.; Giannis, A. Tetrahedron 2001, 57, 4863-4866. doi:10.1016/S0040-4020(01)00424-0

70. Fujioka, H.; Komatsu, H.; Nakamura, T.; Miyoshi, A.; Hata, K.; Ganesh, J.; Murai, K.; Kita, Y. Chem. Commun. 2010, 46, 4133-4135. doi:10.1039/B925687C

71. Dohi, T.; Nakae, T.; Ishikado, Y.; Kato, D.; Kita, Y. Org. Biomol. Chem. 2011, 9, 6899-6902. doi:10.1039/c1ob06199b

72. Dohi, T.; Uchiyama, T.; Yamashita, D.; Washimi, N.; Kita, Y. Tetrahedron Lett. 2011, 52, 2212-2215. doi:10.1016/j.tetlet.2010.12.037

73. Moschitto, M. J.; Anthony, D. R.; Lewis, C. A. J. Org. Chem. 2015, 80, 3339-3342. doi:10.1021/acs.joc.5b00107

74. Zhang, X.; Hou, W.; Zhang-Negrerie, D.; Zhao, K.; Du, Y. Org. Lett. 2015, 17, 5252-5255. doi:10.1021/acs.orglett.5b02611

75. Singh, F. V.; Wirth, T. Chem. - Asian J. 2014, 9, 950-971. doi:10.1002/asia.201301582

76. Dohi, T.; Maruyama, A.; Yoshimura, M.; Morimoto, K.; Tohma, H.; Kita, Y. Angew. Chem., Int. Ed. 2005, 44, 6193-6196. doi:10.1002/anie.200501688

77. Uyanik, M.; Yasui, T.; Ishihara, K. Bioorg. Med. Chem. Lett. 2009, 19, 3848-3851. doi:10.1016/j.bmcl.2009.03.148

78. Dohi, T.; Sasa, H.; Miyazaki, K.; Fujitake, M.; Takenaga, N.; Kita, Y. J. Org. Chem. 2017, 82, 11954-11960. doi:10.1021/acs.joc.7b02037
79. Wipf, P.; Spencer, S. R. J. Am. Chem. Soc. 2005, 127, 225-235. doi:10.1021/ja044280k

80. Braun, N. A.; Ciufolini, M. A.; Peters, K.; Peters, E.-M. Tetrahedron Lett. 1998, 39, 4667-4670. doi:10.1016/S0040-4039(98)00874-0

81. Braun, N. A.; Ousmer, M.; Bray, J. D.; Bouchu, D.; Peters, K.; Peters, E.-M.; Ciufolini, M. A. J. Org. Chem. 2000, 65, 4397-4408. doi:10.1021/jo000341v

82. Diaba, F.; Ricou, E.; Solé, D.; Teixidó, E.; Valls, N.; Bonjoch, J. ARKIVOC 2007, No. iv, 320-330. doi:10.3998/ark.5550190.0008.429

83. Wardrop, D. J.; Burge, M. S.; Zhang, W.; Ortíz, J. A. Tetrahedron Lett. 2003, 44, 2587-2591. doi:10.1016/S0040-4039(03)00227-2

84. Patil, A. D.; Freyer, A. J.; Reichwein, R.; Carte, B.; Killmer, L. B.; Faucette, L.; Johnson, R. K.; Faulkner, D. J. Tetrahedron Lett. 1997, 38, 363-364. doi:10.1016/S0040-4039(96)02304-0

85. Honda, T. Pure Appl. Chem. 2010, 82, 1773-1783. doi:10.1351/PAC-CON-09-08-06

86. Mizutani, H.; Takayama, J.; Honda, T. Heterocycles 2004, 62, 343-355. doi:10.3987/COM-03-S(P)14

87. Wardrop, D. J.; Burge, M. S. J. Org. Chem. 2005, 70, 10271-10284 doi:10.1021/jo051252r

88. Christodoulou, M. S.; Kasiotis, K. M.; Fokialakis, N.; Tellitu, I.; Haroutounian, S. A. Tetrahedron Lett. 2008, 49, 7100-7102. doi:10.1016/j.tetlet.2008.09.098

89. Liang, J.; Chen, J.; Du, F.; Zeng, X.; Li, L.; Zhang, H. Org. Lett. 2009, 11, 2820-2823. doi:10.1021/ol901005x

90. Wang, K.; Fu, X.; Liu, J.; Liang, Y.; Dong, D. Org. Lett. 2009, 11, 1015-1018. doi:10.1021/ol802952e

91. Wang, J.; Yuan, Y.; Xiong, R.; Zhang-Negrerie, D.; Du, Y.; Zhao, K. Org. Lett. 2012, 14, 2210-2213. doi:10.1021/ol300418h

92. Sreenithya, A.; Sunoj, R. B. Org. Lett. 2014, 16, 6224-6227. doi:10.1021/ol503161g

93. Abdellaoui, H.; Xu, J. Tetrahedron 2014, 70, 4323-4330. doi:10.1016/j.tet.2014.05.008

94. Southgate, R.; Branch, C.; Coulton, S.; Hunt, E. In Recent Progress in the Chemical Synthesis of Antibiotics and Related Microbial Products; Luckacs, G., Ed.; Spirnger: Berlin, 1993; Vol. 2, pp 621-630.

95. Jin, C.-Y.; Du, J.-Y.; Zeng, C.; Zhao, X.-H.; Cao, Y.-X.; Zhang, X.-Z.; Lu, X.-Y.; Fan, C.-A. Adv. Synth. Catal. 2014, 356, 2437-2444. doi:10.1002/adsc.201400191

96. Chen, Z.-W.; Zhu, Y.-Z.; Ou, J.-W.; Wang, Y.-P.; Zheng, J.-Y. J. Org. Chem. 2014, 79, 10988-10998. doi:10.1021/jo5020307

97. Wen, J.; Wei, W.; Xue, S.; Yang, D.; Lou, Y.; Gao, C.; Wang, H. J. Org. Chem. 2015, 80, 4966-4972. doi:10.1021/acs.joc.5b00361

98. Dohi, T.; Maruyama, A.; Minamitsuji, Y.; Takenaga, N.; Kita, Y. Chem. Commun. 2007, 1224-1226. doi:10.1039/B616510A

99. Jaegli, S.; Dufour, J.; Wei, H.-I.; Piou, T.; Duan, X.-H.; Vors, J.-P.; Neuville, L.; Zhu, J. Org. Lett. 2010, 12, 4498-4501. doi:10.1021/ol101778c

100.Dohi, T.; Takenaga, N.; Fukushima, K.-i.; Uchiyama, T.; Kato, D.; Motoo, S.; Fujioka, H.; Kita, Y. Chem. Commun. 2010, 46, 7697-7699. doi:10.1039/C0CC03213A

101. Yu, Z.; Ju, X.; Wang, J.; Yu, W. Synthesis 2011, 6, 860-866. doi:10.1055/s-0030-1259444

102.Zhang, D.-Y.; Xu, L.; Wu, H.; Gong, L.-Z. Chem. - Eur. J. 2015, 21, 10314-10317. doi:10.1002/chem.201501583

103. Ousmer, M.; Braun, N. A.; Bavoux, C.; Perrin, M.; Ciufolini, M. A. J. Am. Chem. Soc. 2001, 123, 7534-7538. doi:10.1021/ja016030z

104.Ousmer, M.; Braun, N. A.; Ciufolini, M. A. Org. Lett. 2001, 3, 765-767. doi:10.1021/ol015526i 
105. Mizutani, H.; Takayama, J.; Soeda, Y.; Honda, T. Tetrahedron Lett. 2002, 43, 2411-2414. doi:10.1016/S0040-4039(02)00296-4

106. Kita, Y.; Tohma, H.; Inagaki, M.; Hatanaka, K.; Kikuchi, K.; Yakura, T. Tetrahedron Lett. 1991, 32, 2035-2038. doi:10.1016/S0040-4039(00)78901-5

107.Kita, Y.; Tohma, H.; Inagaki, M.; Hatanaka, K.; Yakura, T. J. Am. Chem. Soc. 1992, 114, 2175-2180. doi:10.1021/ja00032a036

108. Kita, Y.; Takada, T.; Ibaraki, M.; Gyoten, M.; Mihara, S.; Fujita, S.; Tohma, H. J. Org. Chem. 1996, 61, 223-227. doi:10.1021/jo951439q

109.Asmanidou, A.; Papoutsis, I.; Spyroudis, S.; Varvoglis, A. Molecules 2000, 5, 874-879. doi:10.3390/50600874

110.Zheng, C.; Wang, L.; Li, J.; Wang, L.; Wang, D. Z. Org. Lett. 2013, 15, 4046-4049. doi:10.1021/ol401863k

111.Huang, J.; Wang, H.; Wu, C.; Wulff, W. D. Org. Lett. 2007, 9, 2799-2802. doi:10.1021/ol070904q

112.Phipps, R. J.; Toste, F. D. J. Am. Chem. Soc. 2013, 135, 1268-1271. doi:10.1021/ja311798q

113.Tohma, H.; Harayama, Y.; Hashizume, M.; Iwata, M.; Kiyono, Y.; Egi, M.; Kita, Y. J. Am. Chem. Soc. 2003, 125, 11235-11240. doi:10.1021/ja0365330

114.Kita, Y.; Yakura, T.; Tohma, H.; Kikuchi, K.; Tamura, Y. Tetrahedron Lett. 1989, 30, 1119-1120. doi:10.1016/S0040-4039(01)80375-0

115.Shigehisa, H.; Takayama, J.; Honda, T. Tetrahedron Lett. 2006, 47, 7301-7306. doi:10.1016/j.tetlet.2006.08.028

116. Honda, T.; Shigehisa, H. Org. Lett. 2006, 8, 657-659. doi:10.1021/ol052841m

117.Dohi, T.; Minamitsuji, Y.; Maruyama, A.; Hirose, S.; Kita, Y. Org. Lett. 2008, 10, 3559-3562. doi:10.1021/ol801321f

118. Kita, Y.; Takada, T.; Gyoten, M.; Tohma, H.; Zenk, M. H.; Eichhorn, J. J. Org. Chem. 1996, 61, 5857-5864. doi:10.1021/jo9606766

119. Kita, Y.; Arisawa, M.; Gyoten, M.; Nakajika, M.; Hamada, R.; Tohma, H.; Takada, T. J. Org. Chem. 1998, 63, 6625-6635. doi:10.1021/jo9807868

120.Roe, C.; Stephenson, G. R. Org. Lett. 2008, 10, 189-192. doi:10.1021/ol702550z

121.Wada, Y.; Otani, K.; Endo, N.; Harayama, Y.; Kamimura, D.; Yoshida, M.; Fujioka, H.; Kita, Y. Org. Lett. 2009, 11, 4048-4050. doi:10.1021/ol901471r

122. Harayama, Y.; Kita, Y. Curr. Org. Chem. 2005, 9, 1567-1588. doi:10.2174/138527205774370568

123. Canesi, S.; Belmont, P.; Bouchu, D.; Rousset, L.; Ciufolini, M. A. Tetrahedron Lett. 2002, 43, 5193-5195. doi:10.1016/S0040-4039(02)00949-8

124. Jain, N.; Ciufolini, M. A. Synlett 2015, 26, 631-634. doi:10.1055/s-0034-1379960

125.Shirley, H. J.; Bray, C. D. Eur. J. Org. Chem. 2016, 1504-1507. doi:10.1002/ejoc. 201501370

126. Uyanik, M.; Sasakura, N.; Mizuno, M.; Ishihara, K. ACS Catal. 2017, 7, 872-876. doi:10.1021/acscatal.6b03380

127.Ley, S. V.; Schucht, O.; Thomas, A. W.; Murray, P. J. J. Chem. Soc., Perkin Trans. 11999, 1251-1252. doi:10.1039/A901798D

128.Wipf, P.; Jung, J.-K.; Rodríguez, S.; Lazo, J. S. Tetrahedron 2001, 57, 283-296. doi:10.1016/S0040-4020(00)00936-4

129.Wipf, P.; Lynch, S. M.; Birmingham, A.; Tamayo, G.; Jiménez, A.; Campos, N.; Powis, G. Org. Biomol. Chem. 2004, 2, 1651-1658. doi:10.1039/B402431A

130.Baxendale, I. R.; Ley, S. V.; Nessi, M.; Piutti, C. Tetrahedron Lett. 2002, 58, 6285-6304. doi:10.1016/S0040-4020(02)00628-2
131. Quideau, S.; Lebon, M.; Lamidey, A.-M. Org. Lett. 2002, 4, 3975-3978. doi:10.1021/ol026855t

132. El Sayed, K. A.; Bartyzel, P.; Shen, X.; Perry, T. L.; Zjawiony, J. K.; Hamman, M. T. Tetrahedron 2000, 56, 949-953. doi:10.1016/S0040-4020(99)01093-5

133.Falomir, E.; Álvarez-Bercedo, P.; Carda, M.; Marco, J. A. Tetrahedron Lett. 2005, 46, 8407-8410. doi:10.1016/j.tetlet.2005.09.146

134.Peuchmaur, M.; Wong, Y.-S. J. Org. Chem. 2007, 72, 5374-5379. doi:10.1021/jo0707986

135.Wong, Y.-S. Chem. Commun. 2002, 686-687. doi:10.1039/B200740A 136.Álvarez-Bercedo, P.; Falomir, E.; Carda, M.; Marco, J. A. Tetrahedron 2006, 62, 9641-9649. doi:10.1016/j.tet.2006.07.076

137. Baxendale, I. R.; Deeley, J.; Griffiths-Jones, C. M.; Ley, S. V.; Saaby, S.; Tranmer, G. K. Chem. Commun. 2006, 2566-2568. doi:10.1039/B600382F

138. Lalic, G.; Corey, E. J. Org. Lett. 2007, 9, 4921-4923. doi:10.1021/ol702323s

139.Pouységu, L.; Sylla, T.; Garnier, T.; Rojas, L.; Charris, J.; Deffieux, D.; Quideau, S. Tetrahedron 2010, 66, 5908-5917. doi:10.1016/j.tet.2010.05.078

140.Koag, M.; Lee, S. Org. Lett. 2011, 13, 4766-4769. doi:10.1021/ol2017033

\section{License and Terms}

This is an Open Access article under the terms of the Creative Commons Attribution License (http://creativecommons.org/licenses/by/4.0). Please note that the reuse, redistribution and reproduction in particular requires that the authors and source are credited.

The license is subject to the Beilstein Journal of Organic Chemistry terms and conditions: (https://www.beilstein-journals.org/bjoc)

The definitive version of this article is the electronic one which can be found at: doi:10.3762/bjoc. 14.152 